Review Article

\title{
Therapeutic Potential of Polyphenols in the Management of Diabetic Neuropathy
}

\author{
Md. Tanvir Kabir, ${ }^{1}$ Nuzhat Tabassum, ${ }^{2}$ Md. Sahab Uddin $\left(D,{ }^{3,4}\right.$ Faissal Aziz, ${ }^{5,6}$ Tapan Behl, ${ }^{7}$ \\ Bijo Mathew, ${ }^{8}$ Md. Habibur Rahman, ${ }^{3}$ Raushanara Akter, ${ }^{1}$ Abdur Rauf $\mathbb{D},{ }^{9}$ and Lotfi Aleya ${ }^{10}$ \\ ${ }^{1}$ Department of Pharmacy, Brac University, Dhaka, Bangladesh \\ ${ }^{2}$ Department of Pharmacy, East West University, Dhaka, Bangladesh \\ ${ }^{3}$ Department of Pharmacy, Southeast University, Dhaka, Bangladesh \\ ${ }^{4}$ Pharmakon Neuroscience Research Network, Dhaka, Bangladesh \\ ${ }^{5}$ Laboratory of Water, Biodiversity \& Climate Change, Cadi Ayyad University, Marrakech, Morocco \\ ${ }^{6}$ National Centre for Studies and Research on Water and Energy (CNEREE), Cadi Ayyad University, Marrakech, Morocco \\ ${ }^{7}$ Chitkara College of Pharmacy, Chitkara University, Rajpura, Punjab, India \\ ${ }^{8}$ Department of Pharmaceutical Chemistry, Amrita School of Pharmacy, Amrita Vishwa Vidyapeetham, \\ AIMS Health Sciences Campus, Kochi 682041, India \\ ${ }^{9}$ Department of Chemistry, University of Swabi, Anbar, Swabi, Khyber Pakhtunkhwa, Pakistan \\ ${ }^{10}$ Chrono-Environnement Laboratory, UMR CNRS 6249, Bourgogne Franche-Comté University, Besançon, France
}

Correspondence should be addressed to Md. Sahab Uddin; msu-neuropharma@hotmail.com

Received 22 March 2021; Accepted 27 April 2021; Published 13 May 2021

Academic Editor: Rajeev K Singla

Copyright (c) $2021 \mathrm{Md}$. Tanvir Kabir et al. This is an open access article distributed under the Creative Commons Attribution License, which permits unrestricted use, distribution, and reproduction in any medium, provided the original work is properly cited.

\begin{abstract}
Diabetic neuropathy $(\mathrm{DN})$ is a common and serious diabetes-associated complication that primarily takes place because of neuronal dysfunction in patients with diabetes. Use of current therapeutic agents in DN treatment is quite challenging because of their severe adverse effects. Therefore, there is an increased need of identifying new safe and effective therapeutic agents. DN complications are associated with poor glycemic control and metabolic imbalances, primarily oxidative stress (OS) and inflammation. Various mediators and signaling pathways such as glutamate pathway, activation of channels, trophic factors, inflammation, OS, advanced glycation end products, and polyol pathway have a significant contribution to the progression and pathogenesis of DN. It has been indicated that polyphenols have the potential to affect DN pathogenesis and could be used as potential alternative therapy. Several polyphenols including kolaviron, resveratrol, naringenin, quercetin, kaempferol, and curcumin have been administered in patients with DN. Furthermore, chlorogenic acid can provide protection against glutamate neurotoxicity via its hydrolysate, caffeoyl acid group, and caffeic acid through regulating the entry of calcium into neurons. Epigallocatechin-3-gallate treatment can protect motor neurons by regulating the glutamate level. It has been demonstrated that these polyphenols can be promising in combating DN-associated damaging pathways. In this article, we have summarized DNassociated metabolic pathways and clinical manifestations. Finally, we have also focused on the roles of polyphenols in the treatment of DN.
\end{abstract}

\section{Introduction}

Diabetic neuropathy (DN) is a common disorder and a microvascular complication of diabetes. Diabetic peripheral neuropathy (DPN) is linked with significant morbidity, mortality, and decreased quality of life [1]. The occurrence of neuropathy in diabetic individuals is around $30 \%$, while up to $50 \%$ of diabetic individuals will develop neuropathy [2]. It has been estimated that around 472 million people will be affected by diabetes by 2030 , while DPN will affect around 236 million individuals globally [3]. In general, DPN can be classified into focal/multifocal varieties and generalized 
polyneuropathies $[4,5]$. Furthermore, this generalized form of DPN can also be divided into atypical and typical forms, depending on the alteration in onset, duration, pathophysiology, clinical manifestations, and associations. Indeed, typical DPN is a progressive and symmetrical length-dependent sensorimotor polyneuropathy.

In addition, typical DPN is the most common symptom of diabetes-related injury of the peripheral nervous system [6]. Since there is an increased rate of DN occurrence, it is important to study DN pathophysiology and therapeutic approaches in detail. DN can be developed on a hyperglycemia background and related metabolic imbalances, primarily oxidative stress (OS). Further complications can take place due to the hyperglycemia-mediated overgeneration of free radicals. Various studies have detected main pathways that are associated with $\mathrm{DN}$, including the induced level of polyol, advanced generation of glycation end products, and other cascades of stress responses [7]. It has been identified that OS plays a crucial role in DN development.

Despite advances in the therapy of diabetes complications including DN, still, there is a deficiency of effective therapeutic agents. Furthermore, current drugs that are available to treat DN involve various common and serious adverse effects (Table 1). There is an increased need of developing novel multitarget therapeutic agents to control more destructive signaling mechanisms in patients with $\mathrm{DN}$. It has been reported that polyphenols [8] are multitarget agents that exert effective antioxidant and anti-inflammatory properties. It has been confirmed by various in vitro and in vivo studies that natural phenolic compounds play important roles in the management of type 2 diabetes via insulindependent mechanisms (Table 2). Besides, polyphenols have the efficacy to fight against various diseases including diabetes and diabetes-associated complications [8-10]. Polyphenols have been reported to exert potent neuroprotective activities in case of diabetes [11].

In order to develop polyphenols as therapeutic agents to treat $\mathrm{DN}$, it is essential to understand the signaling mechanisms that are associated with the advancement of DN and the mechanisms by which polyphenols avert the advancement of these destructive mechanisms. In this article, we have summarized metabolic pathways and clinical manifestations that are associated with DN. Moreover, we have also focused on the roles of polyphenols in the treatment of DN.

\section{Diabetic Neuropathy Pathogenesis- Associated Metabolic Pathways}

It has been revealed that various mechanisms are associated with the development of DN pathogenesis including imbalances in the blood supply to peripheral nerves, gene expression of calcium and sodium channels, vascular system of the thalamic gland, and autoimmune disorders characterized via glial cell activation [71]. The main mediators and signaling mechanisms that are linked with DN include glutamate pathway, activation of channels, trophic factors, inflammation, OS, advanced glycation end products (AGEs), and polyol pathway [72-76].
2.1. Glutamate Pathway. Glutamate is important for various processes including cell migration, cell death, cell differentiation, and synapse plasticity [77]. In the central nervous system (CNS), glutamate also has a significant contribution to the peripheral transduction of sensory inputs [78]. Multiple studies have revealed that glutamate-induced toxicity is present in case of both chronic and acute neurodegenerative disorders of the CNS and peripheral nervous system (PNS) [79]. It has been reported that glutamatergic ligands can induce nociceptive behaviors, which indicates that glutamate is associated with peripheral sensory transduction and nociceptive pathways. In a mouse model of type I diabetes, hyperglycemia markedly elevated the expression of N-methyl-D-aspartate (NMDA) receptors [80]. In addition, activities of spinal NMDARs have been confirmed in nerve injury-mediated pain [81]. Interestingly, spinal NMDAR subunit 2B (NR2B) level was increased in both protein and mRNA levels of STZ-mediated DN, which further resulted in hyperactivity of spinal cord dorsal horn neurons [82]. It has been observed that glutamate (particularly NR2B) induces various DN-associated pathways including apoptosis, inflammation, and OS [83]. In order to combat DN, targeting the glutamate pathway and NR2B as upstream factors of apoptotic, inflammatory, and oxidative mechanisms via phytochemicals is highly promising.

2.2. Activation of Channels. Transient receptor potential vanilloid 1 (TRPV1) channel is associated with multiple modalities of nociceptive stimuli. In a streptozotocin- (STZ-) mediated DN model, the expression of TRPV1 was markedly elevated in individuals with hyperalgesic skin in comparison with the individuals with hypoalgesic and normoalgesic skin $[84,85]$. Various studies have revealed that early stages of DN take place because of the TRPV1 upregulation via protein kinase $\mathrm{C}$ (PKC) and protein kinase A (PKA) [86], which further indicates the contribution of TRPV1 channels in hyperalgesia expression [86]. In case of DN, other TRPV receptors are yet to be properly investigated [87]. TRPV may be generally considered as an auspicious therapeutic target to develop new therapeutic agents for DN. TRPV1 activation-induced $\left[\mathrm{Ca}^{2+}\right]$ transients and found to be commonly altered in hyperalgesia [86]. Therefore, voltage-gated calcium channels $(\mathrm{CaVs})$ are supposed to be associated with painful DN [88]. It has been reported that the $\alpha 2 \delta$ subunits elevated the trafficking and expression of these channels, however might have a contribution to synaptogenesis within the CNS and PNS [89]. Along with CaVs, an increased level of voltage-gated sodium channels (Nav) was detected at the site of neuronal injury in DN [90]. Furthermore, an increased level of methylglyoxal has been identified in the serum of patients with painful DN. Methylglyoxal resulted in mechanical and thermal hyperalgesia when injected into the diabetic mouse models (but not in Nav1.8 knockout mouse models) [91]. Collectively, all these findings suggest the significance of $\mathrm{CaVs}$, Nav, and TRPV1 via multitarget phytochemicals in the DN development (Figure 1). Besides, TRPV1 was found to be coexpressed with glutamate receptors [92]. 
TABLE 1: Common and serious adverse effects of currently available drugs that are used in the treatment of diabetic neuropathy.

\begin{tabular}{|c|c|c|c|}
\hline Drug & Common adverse effects & Serious adverse effects & References \\
\hline Amitriptyline & $\begin{array}{l}\text { Nausea, insomnia, headache, blurred vision, } \\
\text { dizziness, sedation, dry mouth, orthostatic } \\
\text { hypotension, urinary retention }\end{array}$ & $\begin{array}{l}\text { Hyponatraemia, serotonin syndrome, suicidal } \\
\text { thoughts, hepatotoxicity, seizures, cardiac arrhythmias, } \\
\text { interstitial lung disease }\end{array}$ & {$[12-14]$} \\
\hline Gabapentin & $\begin{array}{c}\text { Dry mouth, peripheral oedema, somnolence, } \\
\text { gait disturbance, weight gain, headache, } \\
\text { dizziness }\end{array}$ & $\begin{array}{c}\text { Suicidal thoughts and behavior, Stevens-Johnson } \\
\text { syndrome, seizures, hepatitis, withdrawal reactions, } \\
\text { confusion }\end{array}$ & {$[15]$} \\
\hline Tramadol & $\begin{array}{l}\text { Nausea, headache, dizziness, sweating, } \\
\text { constipation, somnolence }\end{array}$ & $\begin{array}{l}\text { Hallucinations, seizures, opioid abuse/misuse, } \\
\text { serotonin syndrome }\end{array}$ & {$[16]$} \\
\hline Duloxetine & $\begin{array}{l}\text { Dizziness, nausea, headache, dry mouth, } \\
\text { diarrhoea, somnolence, sweating, insomnia, } \\
\text { constipation, tremor }\end{array}$ & Hepatic failure, serotonin syndrome, hypertensive & {$[17-19]$} \\
\hline Venlafaxine & $\begin{array}{l}\text { Nausea, headache, insomnia, vomiting, } \\
\text { diarrhoea, sweating, dry mouth, anorexia, } \\
\text { somnolence }\end{array}$ & $\begin{array}{l}\text { crisis, urinary retention, interstitial lung disease, } \\
\text { hyponatraemia, Stevens-Johnson syndrome, seizures }\end{array}$ & {$[20]$} \\
\hline Pregabalin & $\begin{array}{l}\text { Dry mouth, dizziness, somnolence, weight } \\
\text { gain, weakness, headache, peripheral oedema }\end{array}$ & $\begin{array}{l}\text { Seizures, angioedema, hepatotoxicity, rhabdomyolysis, } \\
\text { Stevens-Johnson syndrome, suicidal thoughts, cardiac } \\
\text { arrhythmia, pulmonary oedema, thrombocytopenia }\end{array}$ & {$[21,22]$} \\
\hline $\begin{array}{l}\text { Tapentadol } \\
\text { extended release } \\
\text { (ER) }\end{array}$ & $\begin{array}{l}\text { Nausea, headache, somnolence, dizziness, } \\
\text { sweating, constipation }\end{array}$ & Same as tramadol and angioedema & [23-26] \\
\hline
\end{tabular}

2.3. Polyol Pathway. Polyol pathway exists in various tissues including blood vessels and peripheral nerve and plays significant roles in DN development [93]. There are two major enzymes that are associated with the polyol pathway including sorbitol dehydrogenase and aldose reductase (AR). These enzymes are found in several tissues including vascular cells, glomerulus, retina, lens, and nerve [94]. Increased levels of blood glucose can result in $\mathrm{AR}$ activation that generates sorbitol from glucose. Indeed, this reaction utilizes nicotinic acid adenine dinucleotide phosphate $(\mathrm{NADPH})$ and generates $\mathrm{NADP}^{+}$. Increased NADPH utilization can decrease the concentration of a decreased level of glutathione (GSH) and elevates its oxidized form GSH disulfide. Since sorbitol is unable to cross the cell membrane, sorbitol accumulation increases blood osmolality which further results in the loss of electrolytes [74, 95]. Increased level of osmosis can lead to injury of cells that are located adjacent to peripheral neurons (Schwann cells) and results in a schwannopathy-associated phenotype of DN $[95,96]$. It has been reported that sorbitol dehydrogenase can trigger the conversion of accrued sorbitol into fructose through oxidation and generation of nicotinic acid adenine dinucleotide. Nonetheless, increased levels of fructose and sorbitol exert harmful actions in nerve cells because of various causes including the reduced level of the osmolality regulator (taurine), regulator of insulin sensitivity (myoinositol), suppression of the $\mathrm{Na}^{+} / \mathrm{K}^{+}$ATPase pump, intracellular $\mathrm{Na}^{+}$ accumulation, ionic homoeostasis through reducing the PKC effect which results in swelling of the axon and axonglia dysfunction, and decreased level of nerve conduction velocity (NCV) [72].

It has been revealed that accumulated glucose can enter into the hexosamine biosynthesis pathway and generates fructose-6-phosphate, which gets eventually converted into uridine diphosphate- $\mathrm{N}$-acetylglucosamine (GlcNAc). In addition, GlcNAc is a sugar moiety that is utilized in $\mathrm{O}$ - or
$\mathrm{N}$-glycosylation of such translated proteins (posttranslational modification) since SP-1 transcription factor results in plasminogen activator inhibitor-1 overexpression and growth factor- $\beta 1$ transformation. Therefore, these factors result in nerve injury by generating mitochondrial superoxides [97]. In animal models, inhibitors of AR were found to be very effective in reducing DN [98]. However, these inhibitors were not that much effective in clinical studies [99], which was partial because of the introduction of lower doses as compared to in vivo studies. Thus, inadequate levels were available to avert the flux through the polyol pathway [98].

\subsection{Oxidative Stress and Advanced Glycation End Products.} In case of OS, oxidation surpasses antioxidant ability in cells because of the imbalance in the level of enzymatic antioxidant catalase (CAT) and superoxide dismutase (SOD) or nonenzymatic factor GSH [100]. In the polyol pathway, NADPH consumption results in negative action in a decreased level of GSH. Increased level of reactive oxygen species (ROS) including hydrogen peroxide $\left(\mathrm{H}_{2} \mathrm{O}_{2}\right)$, hydroxyl radical $\left({ }^{\bullet} \mathrm{OH}\right)$, and superoxide $\left(\mathrm{O}_{2}{ }^{\bullet-}\right)$ was found to damage the proteins and lipid of cells. Furthermore, ROS can result in injury of lipids in the myelin sheath [101]. In a study, Edwards et al. [102] revealed that increased concentration of nitrosative products including nitrotyrosine (NT) and peroxynitrite $\left(\mathrm{ONOO}^{-}\right)$in diabetic individuals is positively associated with DPN. Therefore, the increased lipid peroxidation, and damage rate of DNA and protein. It has been reported that nonenzymatic reactions between the damaged lipids, DNA, or proteins and aldehyde groups of reducing sugars lead to AGEs, which further stimulate ROS generation both during their formation and interaction with the AGE receptor (RAGE) $[103,104]$. In addition, advanced lipoxidation end products are generated via an elevated level 
TABLE 2: Antidiabetic properties of naturally occurring phenolic compounds.

\begin{tabular}{|c|c|c|}
\hline $\begin{array}{l}\text { Naturally occurring phenolic } \\
\text { compounds }\end{array}$ & Effects & References \\
\hline Flavonoids & $\begin{array}{l}\text { (i) Intestinal microbiota } \uparrow \\
\text { (ii) Digestive enzymes } \downarrow \\
\text { (iii) Glucose absorption } \downarrow \\
\text { (iv) Formation of advanced glycation end products (AGEs) } \downarrow\end{array}$ & {$[27-31]$} \\
\hline Catechins & $\begin{array}{l}\text { (i) Insulin sensitivity } \uparrow \\
\text { (ii) Fecal excretion of bile acids and cholesterol } \uparrow \\
\text { (iii) Activation of AMPK } \uparrow \\
\text { (iv) White fat depots } \downarrow \\
\text { (v) Blood lipid } \downarrow \\
\text { (vi) Glycaemia } \downarrow \\
\text { (vii) Pancreatic } \alpha \text {-glucosidase and also } \alpha \text {-amylase and maltase } \downarrow \\
\text { (viii) Generation of reactive oxygen species } \downarrow \\
\text { (ix) } \mathrm{Na}^{+} \text {-dependent glucose transporter } \downarrow \\
\text { (i) Insulin response } \uparrow\end{array}$ & {$[32-38]$} \\
\hline Caffeoylquinic acids & $\begin{array}{l}\text { (ii) Hepatic glucose-6-phosphatase } \downarrow \\
\text { (iii) Human pancreatic and salivary } \alpha \text {-amylase } \downarrow\end{array}$ & {$[39-43]$} \\
\hline Isoflavones & $\begin{array}{l}\text { (i) Hypoglycemic effects through ameliorating insulin resistance and sensitivity } \uparrow \\
\text { (ii) Exerting anti-inflammation property } \uparrow \\
\text { (iii) Digestion of carbohydrate and uptake of glucose in the small intestine } \downarrow \\
\text { (iv) Protecting pancreatic } \beta \text {-cells } \uparrow \\
\text { (v) The mechanism of renal interstitial fibrosis in diabetic nephropathic rat models } \\
\downarrow \\
\text { (vi) Oxidative damage } \downarrow \\
\text { (vii) Maillard reaction and formation of AGEs } \downarrow \\
\text { (i) Insulin resistance and glucose intolerance } \uparrow\end{array}$ & {$[44-46]$} \\
\hline Hydroxycinnamic acids & $\begin{array}{l}\text { (i) Insulin resistance and glucose intolerance } \uparrow \\
\text { (ii) Glucokinase activity } \uparrow \\
\text { (iii) } \beta \text {-Cell activity } \uparrow \\
\text { (iv) Antioxidant properties and anti-inflammatory activities } \uparrow \\
\text { (v) Activation of AMP-activated protein kinase } \uparrow \\
\text { (vi) Phosphoenolpyruvate carboxykinase and glucose- } 6 \text {-phosphatase effects in the } \\
\text { liver } \downarrow \\
\text { (vii) Gluconeogenesis and adipogenesis }\end{array}$ & {$[47-50]$} \\
\hline Stilbenoids & $\begin{array}{l}\text { (i) Metabolic control } \uparrow \\
\text { (ii) Pancreatic } \beta \text {-cell and hepatoprotective activity } \uparrow \\
\text { (iii) Insulin sensitivity } \uparrow \\
\text { (iv) DNA integrity } \uparrow \\
\text { (v) Level of digestive enzymes } \downarrow \\
\text { (vi) Oxidative stress and inflammation } \downarrow\end{array}$ & {$[51-57]$} \\
\hline Tannins & $\begin{array}{l}\text { (i) Uptake of glucose in adipose tissue through phosphorylation of IRS- } 1 \uparrow \\
\text { (ii) Phosphorylation of AMPK } \uparrow \\
\text { (iii) Formation of AGEs and enzymatic action of sucrose, lactase, and maltase } \downarrow \\
\text { (iv) Activities of } \alpha \text {-amylase and } \alpha \text {-glucosidase } \downarrow \\
\text { (i) Target digestive enzymes } \downarrow\end{array}$ & {$[35,58,59]$} \\
\hline Procyanidins & $\begin{array}{l}\text { (ii) AMPK and insulin signaling pathways } \uparrow \\
\text { (iii) Cellular expression of NAD }{ }^{+} \text {and SIRT1 levels } \uparrow \\
\text { (iv) Proinflammatory cytokine expression } \downarrow \\
\text { (i) Antioxidant } \uparrow\end{array}$ & {$[60-63]$} \\
\hline Anthocyanins and anthocyanidins & $\begin{array}{l}\text { (ii) Blood glucose regulation } \uparrow \\
\text { (iii) Anti-inflammatory activity } \uparrow \\
\text { (iv) Oxidative damage } \downarrow \\
\text { (v) Concentrations of cholesterol low-density cholesterol and triglycerides }\end{array}$ & {$[64-67]$} \\
\hline Curcumin & $\begin{array}{l}\text { (i) Protecting pancreatic } \beta \text {-cells } \uparrow \\
\text { (ii) Diabetic cardiomyopathy } \downarrow \\
\text { (iii) Insulin resistance } \downarrow \\
\text { (iv) Oxidative damage } \downarrow\end{array}$ & {$[44,68-70]$} \\
\hline
\end{tabular}

Note: $\uparrow=$ induction; $\downarrow$ = inhibition. 


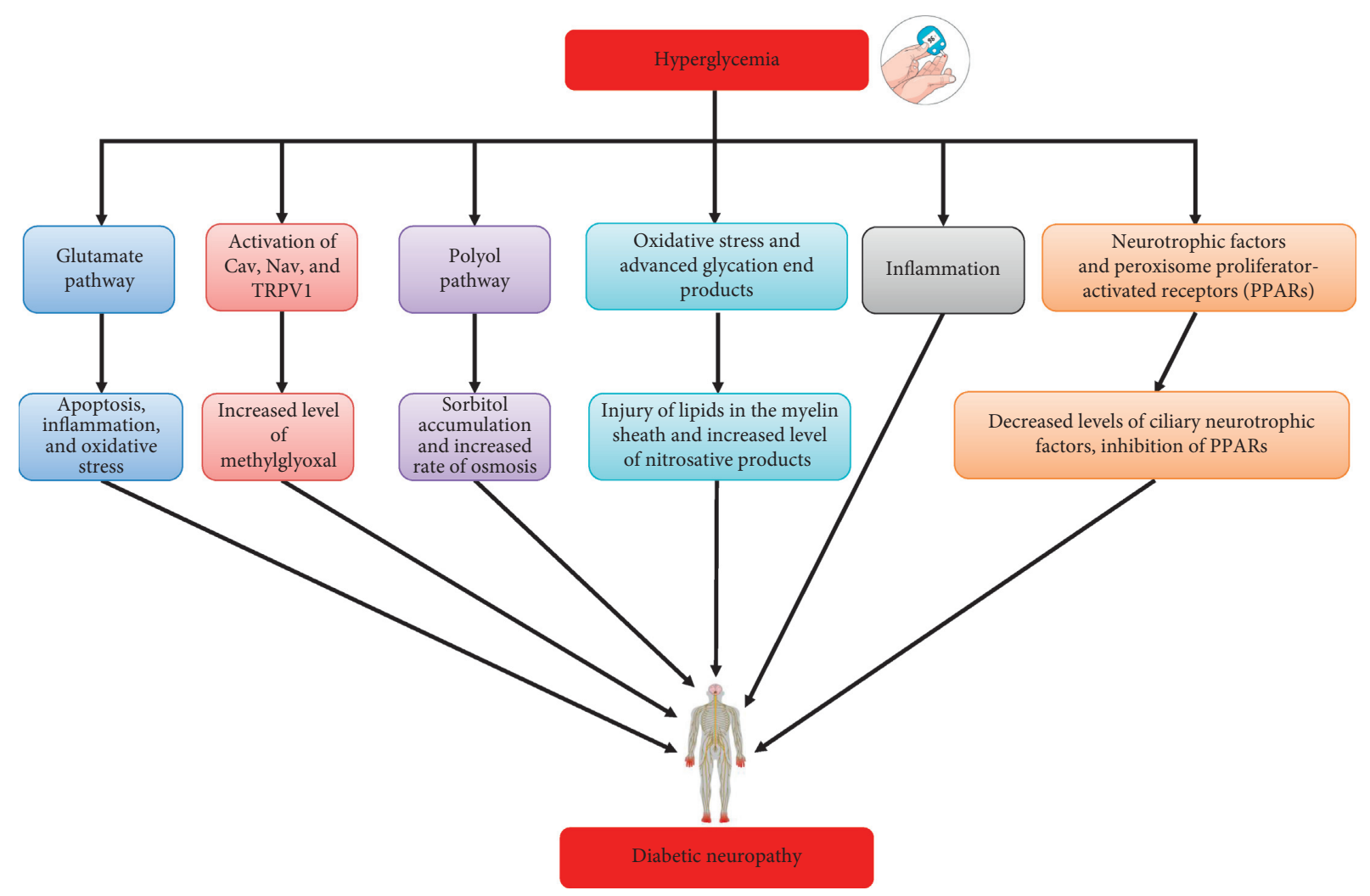

FIGURE 1: Diabetic neuropathy pathogenesis-associated metabolic pathways.

of OS-stimulated lipid peroxidation along with altered lipid metabolism [105].

Other enzymes including PKC- $\beta, 12 / 15$-lipoxygenase, $\mathrm{Na}^{+} / \mathrm{H}^{+}$exchanger, and NADPH oxidase are also associated with ROS generation in DN individuals [106, 107]. Indeed, PKC- $\beta$ has a contribution to nerve activity and DN pathogenesis [108]. Interestingly, streptozotocin- (STZ-) induced diabetic rat models revealed the positive outcomes of the PKC- $\beta$ inhibitor on DN in decreasing free radicals [109]. In case of hyperglycemia, the mitochondrial membrane's potential is disturbed, and it secretes cytochrome $\mathrm{c}$ which then causes activation of procaspase- 9 along with apoptotic protease activating factor-1 (Apaf-1) resulting in the caspase- 3 activation in neurons $[110,111]$. In a STZ-induced rat model of diabetes, Zherebitskaya et al. [112] revealed that an increased level of glucose reduced manganese-containing superoxide dismutase (MnSOD) and elevated level of ROS in axons which predominantly resulted in the injury of dystrophic structures and axon outgrowth. Collectively, these findings regarding OS indicate that regulating the level of ROS in patients with diabetes might be a possible way of preventing DN.

2.5. Inflammation. Inflammation is the response which is activated via damage in the dorsal root ganglion (DRG), spinal cord, skin, or nerve, which eventually leads to painful sensation. Furthermore, it is linked with diabetes and increased concentrations of inflammatory cytokines including tumor necrosis factor- $\alpha$ (TNF- $\alpha)$ and C-reactive protein in individuals with DN [113]. In a study, Conti et al. [114] observed that STZ-induced diabetes resulted in the infiltration of immune cells including monocytes and macrophages, the neuronal overexpression of interleukin-1 beta (IL-1 $\beta$ ), and the expression of neurotrophin receptor p75 [114]. Moreover, the association of inflammation in DN was demonstrated in a STZ-induced diabetic animal model. It was observed that pioglitazone reduced the level of phosphorylated extracellular signal-regulated kinases (ERKs), changed the protein kinase $\mathrm{C}$-alpha expression level, and reduced the number of accumulated macrophages in Schwann cells [115]. Since a transcriptional factor comprises 2 subunits including p50 and p65, nuclear factor kappa B $(\mathrm{NF}-\kappa \mathrm{B})$ is located in the cytoplasm in an inhibitory state bound to the inhibitor of nuclear factor- $\kappa \mathrm{B}(\mathrm{I} \kappa \mathrm{B})$.

After the simulation, $\mathrm{I} \kappa \mathrm{B}$ is tagged through ubiquitin for proteasomal degradation leaving active NF- $\kappa \mathrm{B}$. In the active state, $\mathrm{NF}-\kappa \mathrm{B}$ is translocated to the nucleus, where it induces the expression of various survival and inflammatory genes. It has been revealed that the level of NF- $\kappa$ B's p 65 subunit is increased in the myelin sheath of neurons in case of demyelinating polyneuropathies [116]. In a different study, $\mathrm{Ha}$ et al. [117] revealed that hyperglycemia in glial cells induced $\mathrm{NF}-\kappa \mathrm{B}$ activation, which further resulted in increased concentration of various cell adhesion genes and inflammatory genes (TNF- $\alpha$, cyclooxygenase-2 (COX-2), inducible nitric oxide synthase, IL- $1 \beta$, and interleukin 6 (IL-6)). In another study, Bierhaus et al. [118] detected IL-6, receptor for AGEs, and p65 subunit of NF- $\kappa$ B in sural nerve biopsies obtained from people with diabetes. Collectively, these 
results confirmed that inflammatory signaling pathways have a significant contribution in DN pathogenesis which makes them important pharmacological targets via phytochemicals (Figure 1).

2.6. Neurotrophic Factors and Peroxisome Proliferator-Activated Receptors. Neurotrophic factors induce nerve regeneration, mediate normal physiological activities of surviving neurons, and also elevate their resistance to damage. These activities ameliorate the clinical conditions of patients with DN [119]. It has been observed that deficiency of neurotrophin plays a role in DN pathogenesis. Interestingly, the levels of ciliary neurotrophic factor, insulin-like growth factors, neurotrophin-3/4/5, and brain-derived neurotrophic factor (BDNF) were decreased in the muscles of patients with DN [120]. Indeed, nerve growth factor (NGF) can decrease these neurotrophin imbalances [119]. Preclinical experiments supported the idea that influencing neurotrophic factors via phytochemicals may be a potent therapeutic strategy for various types of peripheral nerve disease.

It is known that peroxisome proliferator-activated receptors (PPARs) are a group of nuclear receptor proteins. By binding with the lipophilic stimulant, PPAR mediates the expression of proximal genes that are associated with hepatocarcinogenesis, lipid hemostasis, proximal proliferation, and beta-oxidation of fatty acids [121-123]. There are 3 major subtypes of PPARs including $\alpha, \beta / \delta$, and $\gamma$ that have a significant contribution in regulating inflammatory processes, morphogenesis, glucose, mobilization of lipids, storage, and metabolism [122, 124, 125]. PPARs work together with various cellular transcription factors including activated protein-1 (AP-1), signal transducer/activator of transcription-1, and NF- $\kappa \mathrm{B}$ [125]. Furthermore, PPARs suppress the expressions of chemokines and proinflammatory genes (interleukin 1 beta (IL-1 $\beta$ ) and TNF- $\alpha$ ) and decrease the sensation of pain [126]. Agonists of PPAR gamma (PPAR $-\gamma$ ) including rosiglitazone and pioglitazone are commonly suggested to treat insulin resistance and hyperglycemia [127] and to reduce the activation of spinal nociceptive neurons in type II diabetic rat models [128]. Furthermore, PPAR agonists have the future potential to be used as novel analgesics in treating various chronic pain conditions including DN. Nevertheless, their possible adverse effects need to be carefully considered during targeting PPAR signaling pathway as analgesics [129]. Thus, there is a growing research interest regarding the use of PPAR agonists to decrease DN.

\section{Clinical Manifestations of Diabetic Neuropathy}

DPN might present with various clinical signs and symptoms. In some cases, patients might be completely asymptomatic; however, foot ulcer might be the first presentation. Nevertheless, other individuals might exhibit one or multiple different symptoms including numbness, paresthesia, and neuropathic pain (frequently stated as aching, shooting, lancinating, or burning) which may range from mild to severe, which can lead to severe suffering [130]. In addition, these symptoms might be constant or sporadic. Interestingly, sensory symptoms might persist for a short duration before they vanish completely, or they might become chronic.

Sensory signs and symptoms first appear in the distal foot/toes. Pinprick and light touch of the distal foot is normally impaired on first physical examination and then more advanced motor (particularly loss of muscle bulk, loss of ankle reflex, clawing of the toes, and weakness) and sensory (specifically proprioception loss and vibration) abnormalities. It spreads proximally up the leg before affecting the upper limbs and fingertips as the disease advances. Physical examination for individuals with painful DPN is typically unclear as compared to those without neuropathic pain. Nonetheless, certain people might contain pure small fiber neuropathy, which can lead to a loss of small fiber modalities (particularly pinprick and loss of temperature sensation) with normal large fiber activity [6]. It was observed that a small number of individuals possess the socalled "irritable nociceptor" phenotype with "positive" sensory signs including hyperalgesia and allodynia $[131,132]$.

\section{Polyphenols in the Treatment of Diabetic Neuropathy}

It has been reported that around 800 plants might contain antidiabetic properties. So far, various phytochemicals including kolaviron, resveratrol, naringenin, quercetin, kaempferol, and curcumin (Figure 2) have been administered in patients with DN. However, it is essential to detect the phytochemicals that can be used in the treatment of DN. In the following sections, we have summarized the cellular signaling pathways and pharmacological targets that are associated with the therapeutic effect of polyphenols in DN.

4.1. Nonenzymatic and Enzymatic Antioxidant Performance. In diabetic animals, hyperglycemia decreases the effect of antioxidant enzymes with nonenzymatic glycosylation and results in OS [133]. In DN development, stimulation of some negative effects including generation of free radicals by OS, lower GSH levels, $\mathrm{Cu} / \mathrm{Zn} \mathrm{SOD}$, glutathione S-transferase, decreased glutathione peroxidase (GPx), oxidations of leukocytes and catecholamines, elevated mitochondrial leak, perglycemia, and ischemia play a major destructive role [133-136]. Various antioxidants, particularly polyphenols, have exerted some promising activities in the experimental DN treatment. In experimental DN, $\alpha$-lipoic acid treatment averted neurovascular irregularities. In diabetic rat models, this treatment also attenuated GSH levels, digital nerve conduction velocity, and nerve blood flow via increasing free radical scavenging activity $[137,138]$. Probucol is a strong free radical scavenger and an inhibitor of low-density lipoprotein oxidation that normalizes both electrophysiology and nerve blood flow [139]. In a study, Al-Rejaie et al. [140] revealed that naringenin contains antioxidant properties. 


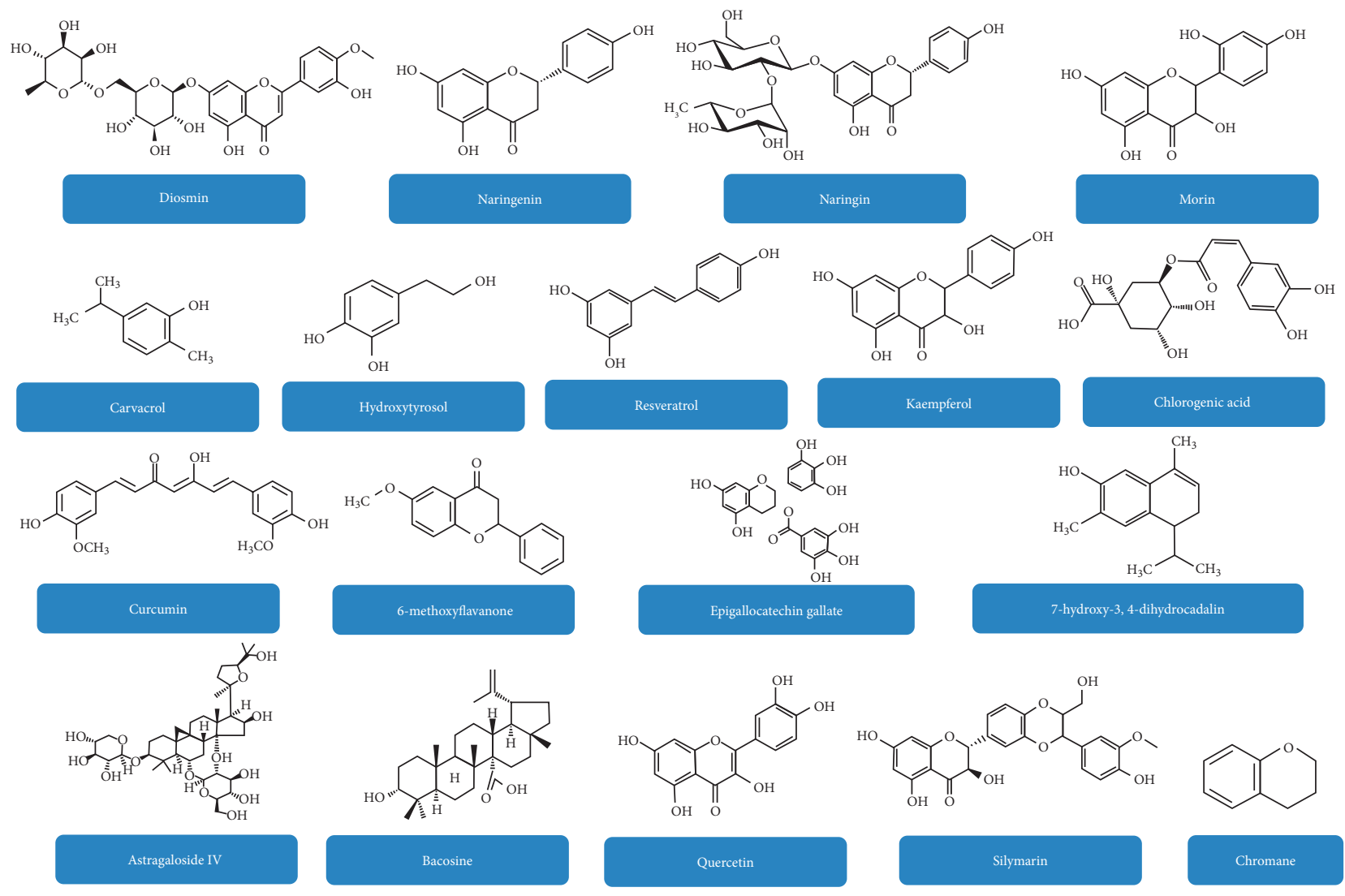

FIGURE 2: Chemical structures of various polyphenolic compounds that can be effective in the treatment of diabetic neuropathy.

Moreover, it inhibited the levels of nitric oxide (NO) and thiobarbituric acid reactive substances (TBARS) and attenuated the decreased concentrations of GPX and CAT in STZ-induced diabetic rat models [140, 141].

Resveratrol (a polyphenolic compound) (Figure 2) protected neural tissues from diabetes-mediated OS via decreasing the levels of malondialdehyde (MDA), xanthine oxidase (XO), and NO in the brain stem, spinal cord, cortex, hippocampus, and cerebellum via increasing the level of GSH in diabetic rat models [142]. In addition, apocynin and curcumin attenuated the elevated spinal $\mathrm{H}_{2} \mathrm{O}_{2}$ level and level of MDA and increased the level of SOD in STZ-induced diabetic rat models. It has been confirmed that curcumin suppressed the activation of spinal NADPH oxidases, the major enzymes that generate ROS via reversing the upregulation of phagocyte NADPH oxidase subunits (gp91 ${ }^{\text {phox }}$ and $\mathrm{p} 47^{\mathrm{phox}}$ ) [143]. More related cellular signaling pathways and pharmacological targets that are associated with the antioxidant property of polyphenols have been summarized in Table 3.

4.2. Prevention of the Inflammatory Response and Proinflammatory Cytokines. Proinflammatory alterations that are seen in diabetes have a significant contribution to the pathogenesis of retinopathy, nephropathy, neuropathy, and atherosclerosis [175]. Production of hyperglycemia-mediated ROS is directly associated with the DN pathogenesis.
Indeed, these ROS might trigger the generation of IL- $1 \beta$ and TNF- $\alpha$. In the CNS, insulin resistance and hyperglycemia are linked with the TNF- $\alpha$ signaling pathway, which might trigger pain and hyperalgesia in DN [176-178]. Various studies have revealed that suppression of TNF- $\alpha$ decreased hyperalgesia in models of painful DN [179]. It has been confirmed that TNF- $\alpha$ intraplantar injection is linked with thermal hyperalgesia and mechanical allodynia in rat models $[74,176,180]$. IL- $1 \beta$ can be obtained from various cell types including Schwann cells, endothelial cells, mononuclear cells, synoviocytes, and fibroblasts and has a significant contribution in triggering mechanical hyperalgesia. In the mouse model of experimental neuropathy, it neutralized the IL-1 receptors that further resulted in the reduction of painrelated behavior $[181,182]$.

Increased lipid level and hyperglycemia resulted in activation of $\mathrm{NF}-\kappa \mathrm{B}$ that has a significant contribution to the generation of ROS and TNF- $\alpha$, which further induces inflammatory demyelination. NF- $\kappa \mathrm{B}$ might increase metabolic disorders including diabetes and trigger inflammation [183]. Inhibitor of NF- $\kappa \mathrm{B}(\mathrm{I} \kappa \mathrm{B}-\alpha)$ and $\mathrm{p} 65$ are the subunits of NF$\kappa \mathrm{B}$ that are overexpressed in sural nerve macrophages in chronic and acute inflammatory demyelinating polyneuropathies $[116,184]$. In STZ-induced DN rat models, it has been confirmed that resveratrol exerts anti-inflammatory property via reducing the expression of $\mathrm{I} \kappa \mathrm{B}-\alpha$ and $\mathrm{p} 65$ and ameliorating the increased concentrations of NF- $\kappa \mathrm{B}$, IL6, COX-2, and TNF- $\alpha$ [169]. Furthermore, resveratrol 
TABle 3: Polyphenols in the treatment of diabetic neuropathy.

\begin{tabular}{|c|c|c|c|c|c|}
\hline Polyphenols & $\begin{array}{l}\text { Animal } \\
\text { models }\end{array}$ & Duration & Dosage & Effects & References \\
\hline Diosmin & $\begin{array}{l}\text { STZ-induced } \\
\text { diabetic rats }\end{array}$ & 4 weeks & 50 and $100 \mathrm{mg} / \mathrm{kg} /$ day & $\begin{array}{c}\text { Increased tail-flick latency; decreased } \\
\text { traveling duration; increased concentration } \\
\text { of SOD and GSH; decreased levels of MDA } \\
\text { and NO }\end{array}$ & {$[144]$} \\
\hline Hydroxytyrosol & $\begin{array}{l}\text { STZ-induced } \\
\text { diabetic rats }\end{array}$ & 6 weeks & 10 and $100 \mathrm{mg} / \mathrm{kg} /$ day & $\begin{array}{c}\text { Reduced thermal nociception; elevated paw } \\
\text { withdrawal threshold and } \mathrm{Na}^{+} / \mathrm{K}^{+} \text {ATPase } \\
\text { activity; increased } \mathrm{MNCV} \text { level }\end{array}$ & {$[145]$} \\
\hline Kolaviron & $\begin{array}{l}\text { STZ-induced } \\
\text { diabetic rats }\end{array}$ & 6 weeks & 100 and $200 \mathrm{mg} / \mathrm{kg} /$ day & $\begin{array}{c}\text { Reduced level of OS, IL- } 1 \beta \text {, TNF- } \alpha \text {, MDA, } \\
\text { and TBARS; elevated concentrations of GSH, } \\
\text { CAT, and GPx }\end{array}$ & {$[146]$} \\
\hline Carvacrol & $\begin{array}{l}\text { STZ-induced } \\
\text { diabetic rats }\end{array}$ & 7 weeks & 25,50 , and $100 \mathrm{mg} / \mathrm{kg} /$ day & $\begin{array}{l}\text { Increased SOD level; decreased } \\
\text { concentrations of IL-1 } \beta, \text { MDA, and TNF- } \alpha \\
\text { Increased tail-flick latency and paw }\end{array}$ & [147] \\
\hline Naringenin & $\begin{array}{l}\text { STZ-induced } \\
\text { diabetic rats }\end{array}$ & 5 weeks & 25 and $50 \mathrm{mg} / \mathrm{kg} /$ day & $\begin{array}{c}\text { withdrawal; elevated NGF and IGF-1 in } \\
\text { sciatic nerves; decreased IL- } 1 \beta \text { and TNF- } \alpha \\
\text { levels; increased concentrations of CAT, } \\
\text { GSH, and GPx }\end{array}$ & {$[140]$} \\
\hline Naringin & $\begin{array}{l}\text { STZ-induced } \\
\text { diabetic rats }\end{array}$ & 4 weeks & 40 and $80 \mathrm{mg} / \mathrm{kg} /$ day & $\begin{array}{l}\text { Reduced mechanotactile allodynia, } \\
\text { oxidative-nitrosative stress, and TNF- } \alpha \text { level; } \\
\text { increased tail-flick latency and nociceptive } \\
\text { threshold; increased concentrations of } \\
\text { MNCV and SOD }\end{array}$ & {$[141]$} \\
\hline & $\begin{array}{l}\text { STZ-induced } \\
\text { diabetic rats }\end{array}$ & 6 weeks & $100 \mathrm{mg} / \mathrm{kg} /$ day & $\begin{array}{l}\text { Decreased thermal nociception, levels of } \\
\text { TNF- } \alpha \text { and IL-10; increased tail-flick latency } \\
\text { and paw withdrawal threshold }\end{array}$ & [148] \\
\hline Curcumin & $\begin{array}{l}\text { STZ-induced } \\
\text { diabetic rats }\end{array}$ & 3 weeks & $200 \mathrm{mg} / \mathrm{kg} /$ day & $\begin{array}{l}\text { Decreased mechanical allodynia and thermal } \\
\text { hyperalgesia; increased paw withdrawal } \\
\text { threshold; decreased AR, prostaglandin } \\
\text { peroxidase, and COX levels }\end{array}$ & [149] \\
\hline & $\begin{array}{l}\text { STZ-induced } \\
\text { diabetic rats }\end{array}$ & 14 days & $200 \mathrm{mg} / \mathrm{kg} /$ day & $\begin{array}{l}\text { Increased paw withdrawal threshold and } \\
\text { SOD level; decreased levels of MDA and } \\
\qquad \mathrm{H}_{2} \mathrm{O}_{2} \text { in the spinal cord }\end{array}$ & {$[143]$} \\
\hline $\begin{array}{l}\text { Curcumin and } \\
\text { gliclazide }\end{array}$ & $\begin{array}{l}\text { STZ-induced } \\
\text { diabetic rats }\end{array}$ & 5 weeks & $100 \mathrm{mg} / \mathrm{kg} /$ day & $\begin{array}{l}\text { Increased mechanical hyperalgesia } \\
\text { threshold, hot-plate, and tail-flick latencies; } \\
\text { decreased levels of peroxynitrite, LPO, and } \\
\text { TNF- } \alpha\end{array}$ & {$[150]$} \\
\hline $\begin{array}{l}\text { Curcumin and } \\
\text { resveratrol }\end{array}$ & $\begin{array}{l}\text { STZ-induced } \\
\text { diabetic rats }\end{array}$ & 4 weeks & $\begin{array}{l}\text { Curcumin = } 60 \mathrm{mg} / \mathrm{kg} / \text { day; } \\
\text { resveratrol = } 20 \mathrm{mg} / \mathrm{kg} / \text { day }\end{array}$ & $\begin{array}{l}\text { Increased nociceptive threshold; decreased } \\
\text { levels of brain nitrite and TNF- } \alpha\end{array}$ & [151] \\
\hline Astragaloside IV & $\begin{array}{l}\text { STZ-induced } \\
\text { diabetic rats }\end{array}$ & 12 weeks & 3,6 , and $12 \mathrm{mg} / \mathrm{kg} /$ day & $\begin{array}{c}\text { Increased myelinated fiber density, } \\
\text { myelinated fiber area, and segmental } \\
\text { demyelination; decreased levels of HbA1C; } \\
\text { increased levels of MNCV and GPx; } \\
\text { decreased AR level in erythrocytes; increased } \\
\text { activity of } \mathrm{Na}^{+} / \mathrm{K}^{+} \text {ATPase in nerves and } \\
\text { erythrocytes }\end{array}$ & {$[152]$} \\
\hline $\begin{array}{l}\text { Epigallocatechin } \\
\text { gallate }\end{array}$ & $\begin{array}{l}\text { STZ-induced } \\
\text { diabetic rats }\end{array}$ & 10 weeks & 20 and $40 \mathrm{mg} / \mathrm{kg} /$ day & $\begin{array}{l}\text { Decreased mechanical allodynia and thermal } \\
\text { hyperalgesia; elevated paw withdrawal } \\
\text { pressure; decreased 8-OHdG } \\
\text { immunoreaction, numbers of Fos- } \\
\text { immunoreacted neurons, and colocalization } \\
\text { of 8-OHdG and Fos in laminae I-III } \\
\text { Increased nociceptive threshold and tail-flick } \\
\text { latency; reduced formalin-mediated } \\
\text { nociceptive behavior; decreased } \\
\text { concentrations of nitrite, TBARS, and MDA; } \\
\text { elevated SOD level }\end{array}$ & {$[154]$} \\
\hline
\end{tabular}


TABle 3: Continued.

\begin{tabular}{|c|c|c|c|c|c|}
\hline Polyphenols & $\begin{array}{l}\text { Animal } \\
\text { models }\end{array}$ & Duration & Dosage & Effects & References \\
\hline $\begin{array}{l}\text { Grape seed } \\
\text { proanthocyanidins }\end{array}$ & $\begin{array}{l}\text { STZ-induced } \\
\text { diabetic rats }\end{array}$ & 16 weeks & $\begin{array}{l}125,250, \text { and } 500 \mathrm{mg} / \mathrm{kg} / \\
\text { day }\end{array}$ & $\begin{array}{c}\text { Increased hot-plate latency and nerve } \\
\text { conduction velocity; decreased level of free } \\
\mathrm{Ca}^{2+} \text {; elevated activities of ATPase in sciatic } \\
\text { nerves }\end{array}$ & {$[155]$} \\
\hline Bacosine & $\begin{array}{l}\text { STZ-induced } \\
\text { diabetic rats }\end{array}$ & 30 days & 5 and $10 \mathrm{mg} / \mathrm{kg} /$ day & $\begin{array}{c}\text { Diabetes-linked cognitive impairment; } \\
\text { decreased hyperalgesia; increased levels of } \\
\text { MNCV and SOD; decreased levels of AGEs, } \\
\text { ROS, MDA, TNF- } \alpha \text {, and IL- } 1 \beta\end{array}$ & {$[156]$} \\
\hline 6-Methoxyflavanone & $\begin{array}{l}\text { STZ-induced } \\
\text { diabetic rats }\end{array}$ & - & 10 and $30 \mathrm{mg} / \mathrm{kg} /$ day & $\begin{array}{l}\text { Elevated paw withdrawal threshold and } \\
\text { latency; reduced thermal nociception; } \\
\text { involvement of GABA receptors; increased } \\
\text { flinching response threshold and latency by a } \\
\text { preference for the } \delta \text { - and K-opioid receptors }\end{array}$ & {$[157]$} \\
\hline Chlorogenic acid & $\begin{array}{l}\text { STZ-induced } \\
\text { diabetic rats }\end{array}$ & 14 days & $100 \mathrm{mg} / \mathrm{kg} /$ day & $\begin{array}{c}\text { Increased threshold of mechanical } \\
\text { hyperalgesia; decreased formalin-mediated } \\
\text { nociceptive behavior }\end{array}$ & {$[158]$} \\
\hline $\begin{array}{l}\text { 7-Hydroxy-3,4- } \\
\text { dihydrocadalin }\end{array}$ & $\begin{array}{l}\text { STZ-induced } \\
\text { diabetic rats } \\
\text { and mice }\end{array}$ & - & $\begin{array}{c}0.3-30 \text { and } 30-300 \mathrm{mg} / \mathrm{kg} / \\
\text { day }\end{array}$ & $\begin{array}{c}\text { Decreased mechanical hyperalgesia and } \\
\text { allodynia and formalin-evoked hyperalgesia; } \\
\text { increased withdrawal threshold; reduced } \\
\text { level of MDA }\end{array}$ & [159] \\
\hline Mulberry flavonoids & $\begin{array}{l}\text { ALX-induced } \\
\text { diabetic rats }\end{array}$ & 8 weeks & 0.3 and $0.1 \mathrm{~g} / \mathrm{kg} /$ day & $\begin{array}{l}\text { Reduced myelin breakdown and myelinated } \\
\text { fiber cross-sectional area; decreased } \\
\text { peripheral nerve injury and numbers of } \\
\text { extramedullary fiber of sciatic nerves }\end{array}$ & {$[160]$} \\
\hline Chromane & $\begin{array}{l}\text { STZ-induced } \\
\text { diabetic rats }\end{array}$ & 30 days & 5 and $10 \mathrm{mg} / \mathrm{kg} /$ day & $\begin{array}{c}\text { Decreased mechanical allodynia and thermal } \\
\text { hyperalgesia; increased paw withdrawal } \\
\text { threshold and MNCV level; decreased levels } \\
\text { of AGEs and ROS }\end{array}$ & {$[161]$} \\
\hline Kaempferol & $\begin{array}{l}\text { STZ-induced } \\
\text { diabetic mice }\end{array}$ & 3 weeks & 25,50 , and $100 \mathrm{mg} / \mathrm{kg} /$ day & $\begin{array}{l}\text { Decreased formalin-mediated nociceptive } \\
\text { behavior in phases } 1 \text { and } 2 \text { and oedema size; } \\
\text { reduced hyperalgesia; elevated thermal pain } \\
\text { threshold; decreased levels of IL- } 1 \beta \text {, TNF- } \alpha \text {, } \\
\text { LPO, and nitrite }\end{array}$ & {$[162]$} \\
\hline Oryzanol & $\begin{array}{l}\text { STZ-induced } \\
\text { diabetic rats }\end{array}$ & - & 50 and $100 \mathrm{mg} / \mathrm{kg} /$ day & $\begin{array}{l}\text { Increased pain threshold, hot-plate latency, } \\
\text { and GSH; decreased flinching in diabetic rats } \\
\text { during both quiescent phase and phase } 2 \text { but } \\
\text { not in phase } 1 \text {; reduced nitrite and MDA } \\
\text { levels; attenuated activity of } \mathrm{Na}^{+}-\mathrm{K}^{+} \text {ATPase }\end{array}$ & {$[163]$} \\
\hline $\begin{array}{l}\text { Pepino polyphenolic } \\
\text { extract }\end{array}$ & $\begin{array}{l}\text { STZ-induced } \\
\text { diabetic mice }\end{array}$ & 12 weeks & - & $\begin{array}{c}\text { Decreased concentrations of IL- } 6 \text {, TNF- } \alpha \text {, } \\
\text { AGEs, and ROS; increased GSH and GPx } \\
\text { levels; elevated fascicle with numerous small } \\
\text { myelinated fibers }\end{array}$ & {$[164]$} \\
\hline \multirow{4}{*}{ Quercetin } & $\begin{array}{l}\text { STZ-induced } \\
\text { diabetic rats }\end{array}$ & 2 weeks & $40 \mathrm{mg} / \mathrm{kg} /$ day & $\begin{array}{l}\text { Increased hot-plate, tail-withdrawal latency, } \\
\text { and cold allodynia latency; reduced number } \\
\text { of foot slips }\end{array}$ & {$[165]$} \\
\hline & $\begin{array}{l}\text { STZ-induced } \\
\text { diabetic rats }\end{array}$ & 8 weeks & 10,20, and $40 \mathrm{mg} / \mathrm{kg} /$ day & $\begin{array}{c}\text { Reduced thermal hyperalgesia and } \\
\text { mechanical allodynia; increased } \\
\text { concentrations of MNCV, SOD, and GPx; } \\
\text { decreased levels of TNF- } \alpha \text { and IL- } 1 \beta\end{array}$ & {$[166]$} \\
\hline & $\begin{array}{l}\text { STZ-induced } \\
\text { diabetic rats }\end{array}$ & 4 weeks & $10 \mathrm{mg} / \mathrm{kg} /$ day & $\begin{array}{c}\text { Increased tail-flick latencies and nociceptive } \\
\text { threshold in both diabetic and nondiabetic } \\
\text { mice }\end{array}$ & {$[167]$} \\
\hline & $\begin{array}{l}\text { STZ-induced } \\
\text { diabetic rats }\end{array}$ & 4 weeks & $10 \mathrm{mg} / \mathrm{kg} /$ day & $\begin{array}{c}\text { Decreased thermal nociception; elevated tail } \\
\text { withdrawal latencies and nociceptive } \\
\text { threshold }\end{array}$ & {$[168]$} \\
\hline
\end{tabular}


TABLE 3: Continued.

\begin{tabular}{|c|c|c|c|c|c|}
\hline Polyphenols & $\begin{array}{l}\text { Animal } \\
\text { models }\end{array}$ & Duration & Dosage & Effects & References \\
\hline \multirow{5}{*}{ Resveratrol } & $\begin{array}{l}\text { STZ-induced } \\
\text { diabetic rats }\end{array}$ & 2 weeks & 10 and $20 \mathrm{mg} / \mathrm{kg} /$ day & $\begin{array}{l}\text { Increased tail-flick latency and paw } \\
\text { withdrawal pressure; elevated concentrations } \\
\text { of MNCV and CAT; reduced MDA level }\end{array}$ & [169] \\
\hline & $\begin{array}{l}\text { STZ-induced } \\
\text { diabetic rats }\end{array}$ & 2 weeks & 10 and $20 \mathrm{mg} / \mathrm{kg} /$ day & $\begin{array}{c}\text { Increased MNCV level; decreased } \\
\text { concentrations of p65, MDA, NF- } \kappa \text { B, I } \kappa \text { B- } \alpha \text {, } \\
\text { TNF- } \alpha \text {, IL-6, and COX- } 2\end{array}$ & {$[170]$} \\
\hline & $\begin{array}{l}\text { STZ-induced } \\
\text { diabetic rats }\end{array}$ & 6 weeks & $20 \mathrm{mg} / \mathrm{kg} /$ day & $\begin{array}{c}\text { Decreased cerebral MDA and COX-2; } \\
\text { increased cerebral level of IL- } 4 \text { and GSH }\end{array}$ & {$[171]$} \\
\hline & $\begin{array}{l}\text { STZ-induced } \\
\text { diabetic rats }\end{array}$ & $>6$ weeks & $10 \mathrm{mg} / \mathrm{kg} /$ day & $\begin{array}{l}\text { Decreased concentrations of MDA, XO, and } \\
\text { NO; increased level of GSH in the cortex, } \\
\text { hippocampus, brain stem, cerebellum, and } \\
\text { spinal cord }\end{array}$ & {$[142]$} \\
\hline & $\begin{array}{l}\text { STZ-induced } \\
\text { diabetic rats }\end{array}$ & 2 weeks & $20 \mathrm{mg} / \mathrm{kg} /$ day & $\begin{array}{c}\text { Elevated tail withdrawal threshold and } \\
\text { latencies }\end{array}$ & {$[172]$} \\
\hline Silymarin & $\begin{array}{l}\text { STZ-induced } \\
\text { diabetic rats }\end{array}$ & 8 weeks & 100 and $200 \mathrm{mg} / \mathrm{kg} / \mathrm{day}$ & $\begin{array}{l}\text { Elevated tail-flick latency; decreased } \\
\text { nociceptive scores in both phases of the } \\
\text { formalin test }\end{array}$ & {$[173]$} \\
\hline Morin & $\begin{array}{l}\text { STZ-induced } \\
\text { diabetic rats }\end{array}$ & 3 weeks & 15 and $30 \mathrm{mg} / \mathrm{kg} /$ day & $\begin{array}{c}\text { Increased paw withdrawal and tail-flick } \\
\text { latency; elevated NGF and IGF-1 in sciatic } \\
\text { nerves; decreased levels of IL- } 1 \beta \text {, TNF- } \alpha \text {, and } \\
\text { LPO }\end{array}$ & {$[174]$} \\
\hline
\end{tabular}

8-OHdG: 8-hydroxy-2'-deoxyguanosine; AGEs: advanced glycation end products; ALX: alloxan; AR: aldose reductase; CAT: catalase; COX: cyclooxygenase; DNP: diabetic neuropathy; GABA: gamma-aminobutyric acid; GPx: glutathione peroxidase; GSH: glutathione; HbA1C: hemoglobin A1c; IGF-1: insulin-like growth factor; IL-10: interleukin-10; IL-1 $\beta$ : interleukin 1 beta; LPO: lipid peroxidation; MDA: malondialdehyde; MNCV: motor nerve conduction velocity; NGF: nerve growth factor; NO: nitric oxide; NOS: nitric oxide synthase; OS: oxidative stress; ROS: reactive oxygen species; SOD: superoxide dismutase; STZ: streptozotocin; TBARS: thiobarbituric acid reactive substances; TNF- $\alpha$ : tumor necrosis factor- $\alpha$; XO: xanthine oxidase.

markedly reduced the atherogenic index, serum glucose level, and expression of cerebral COX-2 and MDA [171]. In a study, Deng et al. [147] revealed that carvacrol reduced STZmediated DN by reducing the level of NF- $\kappa \mathrm{B}$ p65 subunit, TNF- $\alpha$, caspase-3, and IL-1 $\beta$ [147]. Kaempferia (a polyphenol) decreased STZ-induced DN via reducing the levels of TNF- $\alpha$ and IL- $1 \beta$ and inhibiting the formalin-triggered nociceptive behavior (Figure 3). Moreover, it improved lipopolysaccharide-mediated inflammatory mediators (such as ROS, IL- $1 \beta$, TNF- $\alpha$, phagocytosis, prostaglandins, and NO) in microglial cells $[162,185]$.

4.3. Antinociceptive Activities. Hyperglycemia-induced ROS generation and lipid peroxidation in sciatic nerves decreased endoneurial blood flow and induced sciatic nerve dysfunctions in case of DN. Indeed, neuropathic pain is a common diabetes-associated complication that takes place due to the induction of the abnormal activity of the CNS or PNS, which further leads to central sensitization, alterations of primary afferent nerves, and sensory abnormalities. Various studies have already confirmed the efficacy of tramadol, dextromethorphan, lamotrigine, phenytoin, pregabalin, gabapentin, tricyclic antidepressants (TCAs), gamma-aminobutyric acid (GABA), and opioids in the treatment of painful sensory neuropathy. Even though these therapeutic agents may relieve the pain by 30 to $50 \%$, their uses are often limited because of marked side effects [175]. Thus, there is an increased need of using polyphenols as alternative therapies. In a plantar heat hyperalgesia test, quercetin (Figure 2) significantly suppressed the increase of paw withdrawal threshold (PWT) in STZ-induced diabetic rat models which was assessed through Hargreaves' test. On a Randall-Selitto paw pressure device, quercetin also markedly elevated mechanical PWT as compared to STZinduced diabetic control rats [141]. In addition to this, quercetin elevated the tail withdrawal latency in both nondiabetic and diabetic mouse models [167]. In a dosedependent manner, it also has markedly elevated the paw and tail withdrawal latency and reduced the number of foot slips of STZ-induced diabetic rat models in comparison with the normal control $[154,165,186]$.

As compared to the control group, Kaur et al. [161] revealed that chromane markedly corrected the reduced PWT of STZ-induced diabetic rat models in hot-plate and tail immersion tests [161]. In diabetic rat models, 6methoxyflavanones and chlorogenic acid elevated mechanical and thermal PWT, respectively [157, 158]. In a different study, in STZ-induced diabetic rat models, Attia et al. [150] showed that combined administration of gabapentin and curcumin resulted in a marked rise in mechanical PWT along with tail-flick and hot-plate latencies. Interestingly, curcumin significantly elevated the pain threshold, reaction times, and tail-flick latencies [148]. As compared to untreated diabetic rat models, curcumin treatment increased the antinociceptive effect in hot-plate and allodynia tests in STZ-induced DN by elevating the pain threshold [149]. It has been reported that diosmin and oryzanol markedly elevated the tail-flick latency in the tail immersion test and decreased thermal hyperalgesia in STZ-induced diabetes 


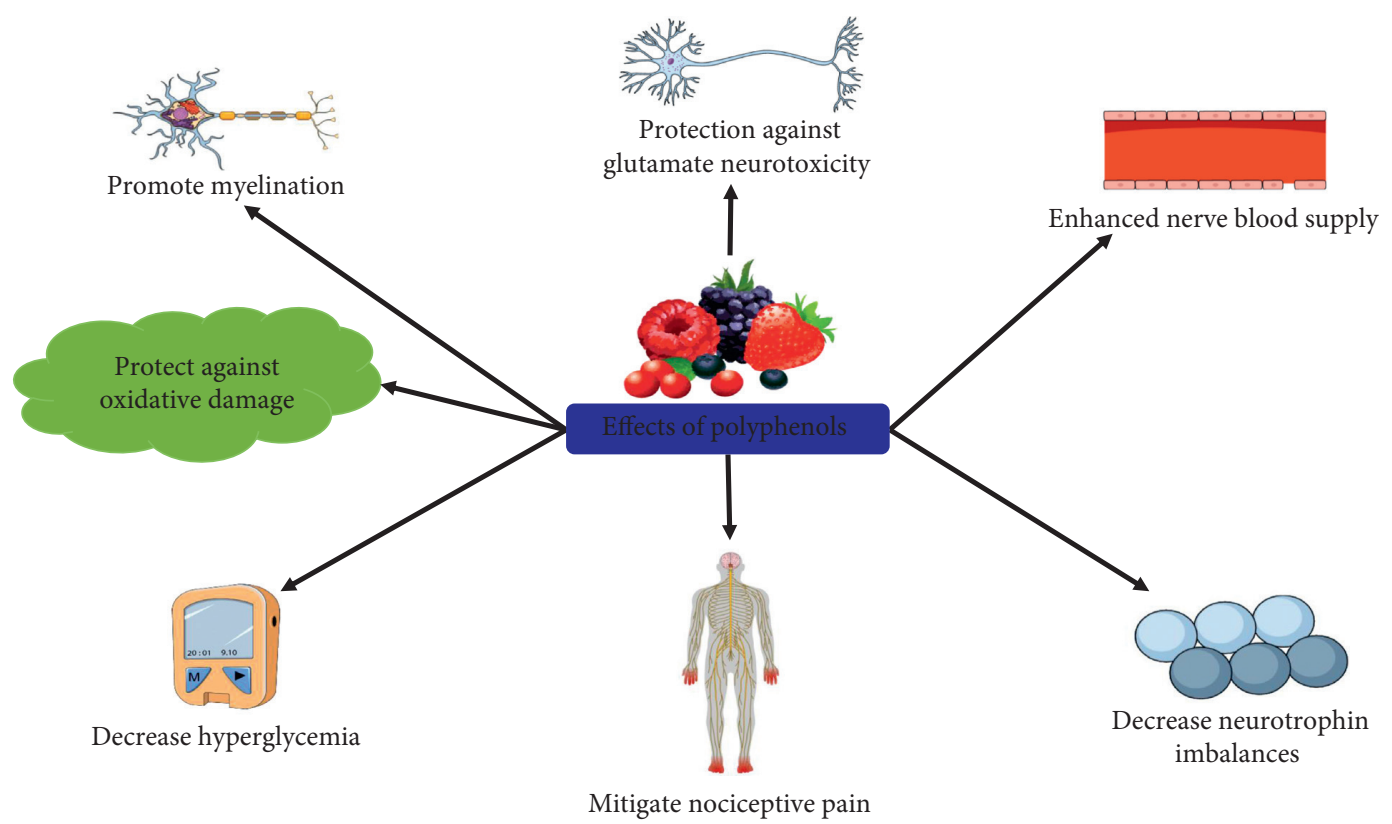

FIgURE 3: Possible effects of polyphenols in the management of diabetic neuropathy.

[163]. In diabetic rat models, treatment with diosmin also markedly ameliorated the shortening of time on walking function tests [144]. In a study, Kumar et al. [169] confirmed that resveratrol treatment significantly corrected the reduction of PWT and tail-flick latency in hot and cold immersion performance [169]. In addition, two polyphenols including 7-hydroxy-3,4-dihydrocadalin and silymarin resulted in a marked reduction of pain scores of the formalin test $[159,173]$.

4.4. Enhancement of Nerve Growth Factors. Multiple complex processes are associated with DN including various molecular changes and sensory modalities. In the nervous system, various neurotrophic factors (especially NGF) affect the population of certain neurons [118]. DN might be regulated via neurotrophins including transient receptor potential ion channels, such as vanilloid receptor 1 and NGF, including its receptors p75 and tyrosine kinase A (TrkA) and their downstream signaling pathways. NGF exerts significant neuroprotective activity, and it causes axonal growth. Indeed, pathological conditions that change NGF levels can induce neurons to lose their activity and die. Following nerve injury and inflammation, NGF level elevates in the nervous system and mediates pain and hyperalgesia that can be decreased via anti-NGF therapy. Interestingly, the complex of TrkA and NGF sensitizes VR1 thereby elevating pain. After the binding of NGF with TrkA, several processes including cell survival, nerve regeneration, and neurite growth pathways will start [187]. IGF-1 is structurally similar to insulin, and it has a significant contribution to cellular growth and proliferation. IGF-1 is also a potent apoptosis inhibitor. In addition, it regulates the development and growth of DNA synthesis and nerve cells [174]. In morintreated diabetic animals, levels of IGF-1 and NGF in sciatic nerves significantly increased as compared to the negative control group [174].

In diabetic rat models, Methycobal and mulberry flavonoids lessened the inhibition of the average optical density of the myelin sheath and myelinated extramedullary fiber cross-sectional area. Interestingly, animals pretreated with $0.3 \mathrm{~g} / \mathrm{kg}$ mulberry flavonoids exhibited ultrastructural properties of myelin, significantly decreased the level of myelin breakdown, and also caused significant axonal improvement [160]. In diabetic rat models, astragaloside IV (a polyphenol) inhibited a reduction in the myelinated fiber area and density and segmental demyelination via reducing the levels of AR and hemoglobin A1c (HbA1C) in erythrocytes, which further increased the plasma insulin concentrations and GPx function in nerves. In STZ-induced diabetic rat models, astragaloside IV increased $\mathrm{Na}^{+} / \mathrm{K}^{+}$ATPase activity in both erythrocytes and nerves [152]. Treatment with grape seed proanthocyanidins ameliorated the abnormal activity of the peripheral nerve and impaired nerve tissues. It also decreased the level of nerve conduction velocity (NCV) and the level of free $\mathrm{Ca}^{2+}$, which further increased the activity of $\mathrm{Ca}^{2+}$-ATPase in sciatic nerves [155]. In diabetic rat models, curcumin treatment gradually recovered cyclooxygenase function in the sciatic nerve [149].

4.5. Glutamate Pathway and NMDA Receptors. In experimental DN models, glutamate receptors and ligands are supposed to be associated with nociceptive behaviors. Besides, it is regarded that glutamate and N-methyl-D-aspartate (NMDA) receptors are associated with peripheral sensory transduction and nociceptive pathways [188]. NMDA receptors also couple with mitogen-activated protein kinase (MAPK) and extracellular signal-regulated kinase (ERK) phosphorylation and activation in the superficial 
laminae of the spinal cord that could be inhibited via treatment with NMDA receptor antagonists [83, 189, 190]. NMDA receptor ion channel-induced entry of calcium has a significant contribution to the activation of extracellular signal-regulated kinase (ERK) and MAPK pathways in painful DN [188]. It has been reported that resveratrol prevented glutamate injuries via blocking the NMDA receptor and inhibited glutamatergic neurotransmission [191, 192]. It also markedly reduced glutamine expression, transportation, synthetase to avert diabetic retinopathy [193]. Resveratrol also suppressed impairments in $\mathrm{Na}^{+} / \mathrm{K}^{+}$ATPase, intracellular ROS generation, mitochondrial dysfunction, and activation of microglia [194, 195]. Furthermore, it decreased the level of glutamate-induced tissue plasminogen activator through ERK and AMPK/mammalian target of rapamycin signaling pathways and reduced the activation of MAPK, which eventually inhibited the activity of the voltage-dependent $\mathrm{Ca}^{2+}$ channel and suppressed induced release of glutamate [196, 197]. Like resveratrol, piceatannol stimulated the expression of nuclear factor erythroid 2-related factor 2-dependent and heme oxygenase1 and thus protected HT22 neuronal cells from glutamatemediated cell death [198].

Chlorogenic acid (a polyphenol) protected against glutamate neurotoxicity via its hydrolysate, caffeoyl acid group, and caffeic acid via controlling the entry of calcium into neurons [199, 200]. Epigallocatechin-3-gallate mediated protection of motor neurons which was found to be linked with the regulation of glutamate concentration [201]. Furthermore, it suppressed glutamate dehydrogenase in pancreatic $\beta$-cells and activated adenosine monophosphateactivated protein kinase to positively influence diabetes [202]. Like quercetin, epigallocatechin-3-gallate also decreased glutamate-mediated raised level of calcium via attenuating PKC and influx of ionotropic $\mathrm{Ca}^{2+}[203-205]$. In diabetic rat models, curcumin prevented intracellular elevation of calcium [206], improved both NR2B gene expression and glutamate level [207, 208], and attenuated excitotoxicity mediated by the NMDA receptor [209]. It also influenced the PI3K/AKT signaling pathway and downstream signaling pathways via $\mathrm{BDNF}$ and $\operatorname{Tr} K \beta$, perhaps via reducing the activation of MAPK/ERK [210, 211]. It was revealed that naringin, chlorogenic acid, and apigenin $8-\mathrm{C}$ glucoside control glutamate pathways [212, 213]. Kaempferol and astragaloside IV attenuated OS and glutamateinduced toxicity $[214,215]$. Therefore, these polyphenols might be good options in preventing complications related to DN (Figure 2).

\section{Future Research Directions}

$\mathrm{DN}$ is one of the most distressing diabetes-associated complications that affects over $30 \%$ of diabetic people worldwide. In addition, there are increasing types of diabetes-mediated peripheral nerve damages including mononeuritis multiplex, mononeuropathy, radiculopathy, diabetic amyotrophy, and autonomic and small fiber neuropathy. DN pathogenesis is multifactorial, and its main categories include ischemic and metabolic. In the treatment of neuropathic pain, even though opioid therapy and neuromodulating drugs, including anticonvulsants and TCAs, are effective treatments, these treatments are expensive. Because of the lack of safe and consistently effective therapies for DN, there is an increased need to develop novel herbal therapies to ameliorate the quality of life of $\mathrm{DN}$ individuals [216]. Various findings suggested that polyphenols exert protective activities by anti-inflammatory and antioxidant pathways. Indeed, polyphenols have the potential to fight against various chronic diseases including diabetes and diabetes-associated complications with less toxic effects in in vitro and animal models [9, 10]. In nutrition, these aforementioned properties have made polyphenols a promising area of research interest [217, 218].

\section{Conclusion}

Polyphenols are potent natural compounds that can be useful to combat DN via influencing various signaling mechanisms with fewer side effects. It has been confirmed that herbal therapies with various polyphenols can exert a positive effect on DN management. Further research regarding novel pathogenicity signaling mechanisms of $\mathrm{DN}$, safety, and efficacy of polyphenols in humans may reveal more effective applications of polyphenols in the management, prevention, and treatment of DN. Nonetheless, more studies are required to develop more effective therapeutic agents for DN.

\section{Conflicts of Interest}

The authors declare that they have no conflicts of interest.

\section{Authors' Contributions}

MSU conceived the original idea and designed the outlines of the study. MTK, NT, and MSU wrote the draft of the manuscript. MTK prepared the figures and tables of the manuscript. FA, TB, BM, MHR, RA, AR, and LA performed the literature review and aided in revising the manuscript. All the authors read and approved the final manuscript.

\section{Acknowledgments}

The authors are grateful to the Pharmakon Neuroscience Research Network, Dhaka, Bangladesh.

\section{References}

[1] V. Bril, "Treatments for diabetic neuropathy," Journal of the Peripheral Nervous System, vol. 17, no. 2, pp. 22-27, 2012.

[2] B. C. Callaghan, H. T. Cheng, C. L. Stables, A. L. Smith, and E. L. Feldman, "Diabetic neuropathy: clinical manifestations and current treatments," The Lancet Neurology, vol. 11, no. 6, pp. 521-534, 2012.

[3] S. Tesfaye and D. Selvarajah, "Advances in the epidemiology, pathogenesis and management of diabetic peripheral neuropathy," Diabetes/Metabolism Research and Reviews, vol. 28, no. 1, pp. 8-14, 2012. 
[4] P. Thomas, "Classification, differential diagnosis, and staging of diabetic peripheral neuropathy," Diabetes, vol. 46, no. 2, pp. S54-S57, 1997.

[5] A. J. M. Boulton, A. I. Vinik, J. C. Arezzo et al., "Diabetic neuropathies: a statement by the American diabetes association," Diabetes Care, vol. 28, no. 4, pp. 956-962, 2005.

[6] S. Tesfaye, A. J. M. Boulton, P. J. Dyck et al., "Diabetic neuropathies: update on definitions, diagnostic criteria, estimation of severity, and treatments," Diabetes Care, vol. 33, no. 10, pp. 2285-2293, 2010.

[7] V. P. Singh, A. Bali, N. Singh, and A. S. Jaggi, "Advanced glycation end products and diabetic complications," The Korean Journal of Physiology \& Pharmacology, vol. 18, no. 1, pp. 1-14, 2014.

[8] K. Hanhineva, R. Törrönen, I. Bondia-Pons et al., "Impact of dietary polyphenols on carbohydrate metabolism," International Journal of Molecular Sciences, vol. 11, no. 4, pp. 1365-1402, 2010.

[9] K. B. Pandey and S. I. Rizvi, "Plant polyphenols as dietary antioxidants in human health and disease," Oxidative Medicine and Cellular Longevity, vol. 2, no. 5, pp. 270-278, 2009.

[10] A. Scalbert, C. Manach, C. Morand, C. Rémésy, and L. Jiménez, "Dietary polyphenols and the prevention of diseases," Critical Reviews in Food Science and Nutrition, vol. 45, no. 4, pp. 287-306, 2005.

[11] G. Cásedas, F. Les, E. González-Burgos, M. P. Gómez-Serranillos, C. Smith, and V. López, "Cyanidin-3-O-glucoside inhibits different enzymes involved in central nervous system pathologies and type-2 diabetes," South African Journal of Botany, vol. 120, pp. 241-246, 2019.

[12] M. Vrethem, J. Boivie, H. Arnqvist, H. Holmgren, T. Lindström, and L.-H. Thorell, "A comparison of amitriptyline and maprotiline in the treatment of painful polyneuropathy in diabetics and nondiabetics," The Clinical Journal of Pain, vol. 13, no. 4, pp. 313-323, 1997.

[13] R. Biesbroeck, V. Bril, P. Hollander et al., "A double-blind comparison of topical capsaicin and oral amitriptyline in painful diabetic neuropathy," Advances in Therapy, vol. 12, no. 2, pp. 111-120, 1995.

[14] D. Bansal, A. Bhansali, D. Hota, A. Chakrabarti, and P. Dutta, "Amitriptyline vs. pregabalin in painful diabetic neuropathy: a randomized double blind clinical trial," $D i$ abetic Medicine, vol. 26, no. 10, pp. 1019-1026, 2009.

[15] P. J. Wiffen, S. Derry, R. F. Bell et al., "Gabapentin for chronic neuropathic pain in adults," Cochrane Database of Systematic Reviews, vol. 2017, no. 6, Article ID CD007938, 2017.

[16] R. M. Duehmke, S. Derry, P. J. Wiffen, R. F. Bell, D. Aldington, and R. A. Moore, "Tramadol for neuropathic pain in adults," Cochrane Database of Systematic Reviews, vol. 2017, no. 6, Article ID CD003726, 2017.

[17] M. P. Lunn, R. A. Hughes, and P. J. Wiffen, "Duloxetine for treating painful neuropathy, chronic pain or fibromyalgia," Cochrane Database of Systematic Reviews, vol. 2014, no. 1, Article ID CD007115, 2014.

[18] S. Brunton, F. Wang, S. B. Edwards et al., "Profile of adverse events with duloxetine treatment," Drug Safety, vol. 33, no. 5, pp. 393-407, 2010.

[19] J. Gahimer, J. Wernicke, I. Yalcin, M. J. Ossanna, M. Wulster-Radcliffe, and L. Viktrup, "A retrospective pooled analysis of duloxetine safety in 23983 subjects," Current Medical Research and Opinion, vol. 23, no. 1, pp. 175-184, 2007.
[20] H. C. Gallagher, R. M. Gallagher, M. Butler, D. J. Buggy, and M. C. Henman, "Venlafaxine for neuropathic pain in adults," Cochrane Database of Systematic Reviews, vol. 2015, no. 8, Article ID CD011091, 2015.

[21] R. Hurley, M. Lesley, M. Adams, C. Brummett, and C. Wu, "Pregabalin as a treatment for painful diabetic peripheral neuropathy: a meta-analysis," Regional Anesthesia and Pain Medicine, vol. 33, no. 5, pp. 389-394, 2008.

[22] S. Derry, R. F. Bell, S. Straube, P. J. Wiffen, D. Aldington, and R. A. Moore, "Pregabalin for neuropathic pain in adults," Cochrane Database of Systematic Reviews, vol. 2019, no. 1, 2019.

[23] A. I. Vinik, D. Y. Shapiro, C. Rauschkolb et al., "A randomized withdrawal, placebo-controlled study evaluating the efficacy and tolerability of tapentadol extended release in patients with chronic painful diabetic peripheral neuropathy," Diabetes Care, vol. 37, no. 8, pp. 2302-2309, 2014.

[24] M. Niesters, P. L. Proto, L. Aarts, E. Y. Sarton, A. M. Drewes, and A. Dahan, "Tapentadol potentiates descending pain inhibition in chronic pain patients with diabetic polyneuropathy," British Journal of Anaesthesia, vol. 113, no. 1, pp. 148-156, 2014.

[25] N. Vadivelu, B. Maslin, A. Kai, A. Legler, G. Kodumudi, and J. Berger, "Tapentadol extended release in the management of peripheral diabetic neuropathic pain," Therapeutics and Clinical Risk Management, vol. 11, pp. 95-105, 2015.

[26] N. Vadivelu, Y. Huang, B. Mirante et al., "Patient considerations in the use of tapentadol for moderate to severe pain," Drug, Healthcare and Patient Safety, vol. 5, pp. 151159, 2013.

[27] G. Loureiro and F. Martel, "The effect of dietary polyphenols on intestinal absorption of glucose and fructose: relation with obesity and type 2 diabetes," Food Reviews International, vol. 35, no. 4, pp. 390-406, 2019.

[28] J. Xiao, X. Ni, G. Kai, and X. Chen, "A review on structureactivity relationship of dietary polyphenols inhibiting $\alpha$-amylase," Critical Reviews in Food Science and Nutrition, vol. 53, no. 5, pp. 497-506, 2013.

[29] V. Gowd, N. Karim, M. R. I. Shishir, L. Xie, and W. Chen, "Dietary polyphenols to combat the metabolic diseases via altering gut microbiota," Trends in Food Science \& Technology, vol. 93, pp. 81-93, 2019.

[30] Y. Xie and X. Chen, "Structures required of polyphenols for inhibiting advanced glycation end products formation," Current Drug Metabolism, vol. 14, no. 4, pp. 414-431, 2013.

[31] J. Xiao, G. Kai, K. Yamamoto, and X. Chen, "Advance in dietary polyphenols as $\alpha$-glucosidases inhibitors: a review on structure-activity relationship aspect," Critical Reviews in Food Science and Nutrition, vol. 53, no. 8, pp. 818-836, 2013.

[32] F. Thielecke and M. Boschmann, "The potential role of green tea catechins in the prevention of the metabolic syndrome-a review," Phytochemistry, vol. 70, no. 1, pp. 11-24, 2009.

[33] R. Park, S.-Y. Kook, J.-C. Park, and I. Mook-Jung, "A $\beta 1-42$ reduces $\mathrm{P}$-glycoprotein in the blood-brain barrier through RAGE-NF- $\kappa$ B signaling," Cell Death \& Disease, vol. 5, no. 6, p. e1299, 2014.

[34] Y. Kobayashi, M. Suzuki, H. Satsu et al., "Green tea polyphenols inhibit the sodium-dependent glucose transporter of intestinal epithelial cells by a competitive mechanism," Journal of Agricultural and Food Chemistry, vol. 48, no. 11, pp. 5618-5623, 2000.

[35] T. Matsui, T. Tanaka, S. Tamura et al., " $\alpha$-Glucosidase inhibitory profile of catechins and theaflavins," Journal of 
Agricultural and Food Chemistry, vol. 55, no. 1, pp. 99-105, 2007.

[36] M. Shimizu, Y. Kobayashi, M. Suzuki, H. Satsu, and Y. Miyamoto, "Regulation of intestinal glucose transport by tea catechins," BioFactors, vol. 13, no. 1-4, pp. 61-65, 2000.

[37] G. Solinas and B. Becattini, "JNK at the crossroad of obesity, insulin resistance, and cell stress response," Molecular Metabolism, vol. 6, no. 2, pp. 174-184, 2017.

[38] F. Li, C. Gao, P. Yan et al., "EGCG reduces obesity and white adipose tissue gain partly through AMPK activation in mice," Frontiers in Pharmacology, vol. 9, p. 1366, 2018.

[39] Y. Narita and K. Inouye, "Kinetic analysis and mechanism on the inhibition of chlorogenic acid and its components against porcine pancreas $\alpha$-amylase isozymes I and II," Journal of Agricultural and Food Chemistry, vol. 57, no. 19, pp. 9218-9225, 2009.

[40] M. Nurul Islam, H. A. Jung, H. S. Sohn, H. M. Kim, and J. S. Choi, "Potent $\alpha$-glucosidase and protein tyrosine phosphatase 1B inhibitors from Artemisia capillaris," Archives of Pharmacal Research, vol. 36, no. 5, pp. 542-552, 2013.

[41] W. J. Arion, W. K. Canfield, F. C. Ramos et al., "Chlorogenic acid and hydroxynitrobenzaldehyde: new inhibitors of hepatic glucose 6-phosphatase," Archives of Biochemistry and Biophysics, vol. 339, no. 2, pp. 315-322, 1997.

[42] C. Henry-Vitrac, A. Ibarra, M. Roller, J.-M. Mérillon, and X. Vitrac, "Contribution of chlorogenic acids to the inhibition of human hepatic glucose-6-phosphatase activity in vitro by svetol, a standardized decaffeinated green coffee extract," Journal of Agricultural and Food Chemistry, vol. 58, no. 7, pp. 4141-4144, 2010.

[43] C. E. G. Reis, J. G. Dórea, and T. H. M. da Costa, "Effects of coffee consumption on glucose metabolism: a systematic review of clinical trials," Journal of Traditional and Complementary Medicine, vol. 9, no. 3, pp. 184-191, 2019.

[44] M. Jin, M.-H. Shen, M.-H. Jin, A.-H. Jin, X.-Z. Yin, and J.-S. Quan, "Hypoglycemic property of soy isoflavones from hypocotyl in Goto-Kakizaki diabetic rats," Journal of Clinical Biochemistry and Nutrition, vol. 62, no. 2, pp. 148-154, 2018.

[45] C. L. Liu, L. Yan, K. R. Cai et al., "Effects of soybean isoflavones on $\mathrm{Wnt} / \beta$-catenin and the TGF- $\beta 1$ signaling pathway in renal tissue of type 2 diabetic rats," Journal of Biological Regulators and Homeostatic Agents, vol. 32, no. 3, pp. 455-464, 2018.

[46] X. Chen, J. Yu, and J. Shi, "Management of diabetes mellitus with puerarin, a natural isoflavone from Pueraria lobata," The American Journal of Chinese Medicine, vol. 46, no. 8, pp. 1771-1789, 2018.

[47] R. B. Kasetti, S. A. Nabi, S. Swapna, and C. Apparao, "Cinnamic acid as one of the antidiabetic active principle(s) from the seeds of Syzygium alternifolium," Food and Chemical Toxicology, vol. 50, no. 5, pp. 1425-1431, 2012.

[48] V. Cherezov, D. M. Rosenbaum, M. A. Hanson et al., "Highresolution crystal structure of an engineered human 2-adrenergic G protein-coupled receptor," Science, vol. 318, no. 5854, pp. 1258-1265, 2007.

[49] M. J. Son, C. W. Rico, S. H. Nam, and M. Y. Kang, "Effect of oryzanol and ferulic acid on the glucose metabolism of mice fed with a high-fat diet," Journal of Food Science, vol. 76, no. 1, pp. H7-H10, 2011.

[50] K. Pei, J. Ou, J. Huang, and S. Ou, "p-Coumaric acid and its conjugates: dietary sources, pharmacokinetic properties and biological activities," Journal of the Science of Food and Agriculture, vol. 96, no. 9, pp. 2952-2962, 2016.
[51] M. Bahmanzadeh, M. T. Goodarzi, A. Rezaei Farimani, N. Fathi, and Z. Alizadeh, "Resveratrol supplementation improves DNA integrity and sperm parameters in streptozotocin-nicotinamide-induced type 2 diabetic rats," Andrologia, vol. 51, no. 8, p. e13313, 2019.

[52] A. Rašković, V. Ćućuz, L. Torović et al., "Resveratrol supplementation improves metabolic control in rats with induced hyperlipidemia and type 2 diabetes," Saudi Pharmaceutical Journal, vol. 27, no. 7, pp. 1036-1043, 2019.

[53] G. Sadi, M. B. Pektaş, H. B. Koca, M. Tosun, and T. Koca, "Resveratrol improves hepatic insulin signaling and reduces the inflammatory response in streptozotocin-induced diabetes," Gene, vol. 570, no. 2, pp. 213-220, 2015.

[54] C. Zhao, C. Yang, S. T. C. Wai et al., "Regulation of glucose metabolism by bioactive phytochemicals for the management of type 2 diabetes mellitus," Critical Reviews in Food Science and Nutrition, vol. 59, no. 6, pp. 830-847, 2019.

[55] E. Bhakkiyalakshmi, D. Shalini, T. V. Sekar, P. Rajaguru, R. Paulmurugan, and K. M. Ramkumar, "Therapeutic potential of pterostilbene against pancreatic beta-cell apoptosis mediated through Nrf2," British Journal of Pharmacology, vol. 171, no. 7, pp. 1747-1757, 2014.

[56] E.-S. M. El-Sayed, A. M. Mansour, and M. E. Nady, "Protective effects of pterostilbene against acetaminophen-induced hepatotoxicity in rats," Journal of Biochemical and Molecular Toxicology, vol. 29, no. 1, pp. 35-42, 2015.

[57] F. Yan, X. Sun, and C. Xu, "Protective effects of resveratrol improve cardiovascular function in rats with diabetes," Experimental and Therapeutic Medicine, vol. 15, no. 2, pp. 1728-1734, 2018.

[58] H. Hosoyama, A. Sugimoto, Y. Suzuki, I. Sakane, and T. Kakuda, "Isolation and quantitative analysis of the $\alpha$-amylase inhibitor in Lagerstroemia speciosa (L.) pers. (Banaba)," Yakugaku Zasshi, vol. 123, no. 7, pp. 599-605, 2003.

[59] T. F. d. Miranda Pedroso, T. R. Bonamigo, J. da Silva et al., "Chemical constituents of Cochlospermum regium (Schrank) Pilg. root and its antioxidant, antidiabetic, antiglycation, and anticholinesterase effects in Wistar rats," Biomedicine \& Pharmacotherapy, vol. 111, pp. 1383-1392, 2019.

[60] K. Ogura, M. Ogura, T. Shoji et al., "Oral administration of apple procyanidins ameliorates insulin resistance via suppression of pro-inflammatory cytokine expression in liver of diabetic ob/ob mice," Journal of Agricultural and Food Chemistry, vol. 64, no. 46, pp. 8857-8865, 2016

[61] Y. Yamashita, L. Wang, F. Nanba, C. Ito, T. Toda, and H. Ashida, "Procyanidin promotes translocation of glucose transporter 4 in muscle of mice through activation of insulin and AMPK signaling pathways," PLoS One, vol. 11, no. 9, Article ID e0161704, 2016.

[62] G. Aragonès, M. Suárez, A. Ardid-Ruiz et al., "Dietary proanthocyanidins boost hepatic NAD+ metabolism and SIRT1 expression and activity in a dose-dependent manner in healthy rats," Scientific Reports, vol. 6, no. 1, 2016.

[63] A. A. Vazquez-Flores, A. I. Martinez-Gonzalez, E. AlvarezParrilla et al., "Proanthocyanidins with a low degree of polymerization are good inhibitors of digestive enzymes because of their ability to form specific interactions: a hypothesis," Journal of Food Science, vol. 83, no. 12, pp. 2895-2902, 2018.

[64] W. Zhu, Q. Jia, Y. Wang, Y. Zhang, and M. Xia, “The anthocyanin cyanidin-3-O- $\beta$-glucoside, a flavonoid, increases hepatic glutathione synthesis and protects hepatocytes 
against reactive oxygen species during hyperglycemia: involvement of a cAMP-PKA-dependent signaling pathway," Free Radical Biology and Medicine, vol. 52, no. 2, pp. 314327, 2012.

[65] M. Roy, S. Sen, and A. S. Chakraborti, "Action of pelargonidin on hyperglycemia and oxidative damage in diabetic rats: implication for glycation-induced hemoglobin modification," Life Sciences, vol. 82, no. 21-22, pp. 1102-1110, 2008.

[66] T. Tsuda, F. Horio, and T. Osawa, "Absorption and metabolism of cyanidin 3-O- $\beta$-D-glucoside in rats," FEBS Letters, vol. 449, no. 2-3, pp. 179-182, 1999.

[67] M. Shi, H. Loftus, A. J. McAinch, and X. Q. Su, "Blueberry as a source of bioactive compounds for the treatment of obesity, type 2 diabetes and chronic inflammation," Journal of Functional Foods, vol. 30, pp. 16-29, 2017.

[68] F. Pivari, A. Mingione, C. Brasacchio, and L. Soldati, "Curcumin and type 2 diabetes mellitus: prevention and treatment," Nutrients, vol. 11, no. 8, p. 1837, 2019.

[69] K. Rashid, S. Chowdhury, S. Ghosh, and P. C. Sil, "Curcumin attenuates oxidative stress induced $\mathrm{NF} \kappa \mathrm{B}$ mediated inflammation and endoplasmic reticulum dependent apoptosis of splenocytes in diabetes," Biochemical Pharmacology, vol. 143, pp. 140-155, 2017.

[70] W. Zha, Y. Bai, L. Xu et al., "Curcumin attenuates testicular injury in rats with streptozotocin-induced diabetes," BioMed Research International, vol. 2018, Article ID 7468019, 10 pages, 2018.

[71] R. A. Kowluru, R. L. Engerman, and T. S. Kern, "Abnormalities of retinal metabolism in diabetes or experimental galactosemia. VI. Comparison of retinal and cerebral cortex metabolism, and effects of antioxidant therapy," Free Radical Biology and Medicine, vol. 26, no. 3-4, pp. 371-378, 1999.

[72] J. Zenker, D. Ziegler, and R. Chrast, "Novel pathogenic pathways in diabetic neuropathy," Trends in Neurosciences, vol. 36, no. 8, pp. 439-449, 2013.

[73] S. Dewanjee, S. Das, A. K. Das et al., "Molecular mechanism of diabetic neuropathy and its pharmacotherapeutic targets," European Journal of Pharmacology, vol. 833, pp. 472-523, 2018.

[74] M. Brownlee, "Biochemistry and molecular cell biology of diabetic complications," Nature, vol. 414, no. 6865, pp. 813-820, 2001.

[75] N. Bhattacharjee, S. Barma, N. Konwar, S. Dewanjee, and P. Manna, "Mechanistic insight of diabetic nephropathy and its pharmacotherapeutic targets: an update," European Journal of Pharmacology, vol. 791, pp. 8-24, 2016.

[76] E. H. Bayram, A. D. Sezer, and H. K. Elçioglu, "Diabetic neuropathy and treatment strategy-new challenges and applications," in Smart Drug Delivery System, A. D. Sezer, Ed., IntechOpen, London, UK, 2016.

[77] N. C. Danbolt, "Glutamate uptake," Progress in Neurobiology, vol. 65, no. 1, pp. 1-105, 2001.

[78] A. Rustioni, "Modulation of sensory input to the spinal cord by presynaptic ionotropic glutamate receptors," Archives italiennes de biologie, vol. 143, no. 2, pp. 103-112, 2005.

[79] B. A. Chizh, "Novel approaches to targeting glutamate receptors for the treatment of chronic pain: review article," Amino Acids, vol. 23, no. 1-3, pp. 169-176, 2002.

[80] H. Roshanravan, E. Y. Kim, and S. E. Dryer, "NMDA receptors as potential therapeutic targets in diabetic nephropathy: increased renal NMDA receptor subunit expression in akita mice and reduced nephropathy following sustained treatment with memantine or MK-801," Diabetes, vol. 65, no. 10, pp. 3139-3150, 2016.

[81] D.-H. Roh, H.-W. Kim, S.-Y. Yoon et al., "Depletion of capsaicin sensitive afferents prevents lamina-dependent increases in spinal N-methyl-d-aspartate receptor subunit 1 expression and phosphorylation associated with thermal hyperalgesia in neuropathic rats," European Journal of Pain, vol. 12 , no. 5, pp. 552-563, 2008.

[82] H.-P. Bai, P. Liu, Y.-M. Wu, W.-Y. Guo, Y.-X. Guo, and X.-L. Wang, "Activation of spinal GABAB receptors normalizes N-methyl-D-aspartate receptor in diabetic neuropathy," Journal of the Neurological Sciences, vol. 341, no. 12, pp. 68-72, 2014.

[83] S. Fakhri, F. Abbaszadeh, L. Dargahi, and M. Jorjani, "Astaxanthin: a mechanistic review on its biological activities and health benefits," Pharmacological Research, vol. 136, pp. 1-20, 2018.

[84] R. M. Pabbidi, S.-Q. Yu, S. Peng, R. Khardori, M. E. Pauza, and L. S. Premkumar, "Influence of TRPV1 on diabetesinduced alterations in thermal pain sensitivity," Molecular Pain, vol. 4, pp. 1744-8069, 2008.

[85] E. V. Khomula, V. Y. Viatchenko-Karpinski, A. L. Borisyuk, D. E. Duzhyy, P. V. Belan, and N. V. Voitenko, "Specific functioning of Cav3.2 T-type calcium and TRPV1 channels under different types of STZ-diabetic neuropathy," Biochimica et Biophysica Acta (BBA)-Molecular Basis of Disease, vol. 1832, no. 5, pp. 636-649, 2013.

[86] M. R. Pabbidi and L. S. Premkumar, "Role of transient receptor potential channels Trpv1 and Trpm8 in diabetic peripheral neuropathy," Journal of Diabetes and Treatment, vol. 2017, no. 4, p. 29, 2017.

[87] L. S. Premkumar and M. Abooj, “TRP channels and analgesia," Life Sciences, vol. 92, no. 8-9, pp. 415-424, 2013.

[88] P. Fernyhough and N. A. Calcutt, "Abnormal calcium homeostasis in peripheral neuropathies," Cell Calcium, vol. 47, no. 2, pp. 130-139, 2010.

[89] A. C. Dolphin, "Calcium channel auxiliary $\alpha 2 \delta$ and $\beta$ subunits: trafficking and one step beyond," Nature Reviews Neuroscience, vol. 13, no. 8, pp. 542-555, 2012.

[90] M. J. Craner, J. P. Klein, M. Renganathan, J. A. Black, and S. G. Waxman, "Changes of sodium channel expression in experimental painful diabetic neuropathy," Annals of Neurology, vol. 52, no. 6, pp. 786-792, 2002.

[91] A. Bierhaus, T. Fleming, S. Stoyanov et al., "Methylglyoxal modification of Nav1.8 facilitates nociceptive neuron firing and causes hyperalgesia in diabetic neuropathy," Nature Medicine, vol. 18, no. 6, pp. 926-933, 2012.

[92] S. Carlton, "Peripheral excitatory amino acids," Current Opinion in Pharmacology, vol. 1, no. 1, pp. 52-56, 2001.

[93] S. Yagihashi, H. Mizukami, and K. Sugimoto, "Mechanism of diabetic neuropathy: where are we now and where to go?" Journal of Diabetes Investigation, vol. 2, no. 1, pp. 18-32, 2011.

[94] R. Ramasamy and I. J. Goldberg, "Aldose reductase and cardiovascular diseases, creating human-like diabetic complications in an experimental model," Circulation Research, vol. 106, no. 9, pp. 1449-1458, 2010.

[95] D. R. Tomlinson and N. J. Gardiner, "Glucose neurotoxicity," Nature Reviews Neuroscience, vol. 9, no. 1, pp. 36-45, 2008.

[96] D. W. Zochodne, "Diabetes mellitus and the peripheral nervous system: manifestations and mechanisms," Muscle \& Nerve, vol. 36, no. 2, pp. 144-166, 2007. 
[97] X.-L. Du, D. Edelstein, L. Rossetti et al., "Hyperglycemiainduced mitochondrial superoxide overproduction activates the hexosamine pathway and induces plasminogen activator inhibitor-1 expression by increasing Sp1 glycosylation," Proceedings of the National Academy of Sciences, vol. 97, no. 22, pp. 12222-12226, 2000.

[98] P. Oates, "Aldose reductase, still a compelling target for diabetic neuropathy," Current Drug Targets, vol. 9, no. 1, pp. 14-36, 2008.

[99] N. Hotta, R. Kawamori, M. Fukuda, and Y. Shigeta, "Longterm clinical effects of epalrestat, an aldose reductase inhibitor, on progression of diabetic neuropathy and other microvascular complications: multivariate epidemiological analysis based on patient background factors and severity of diabetic neuropathy," Diabetic Medicine, vol. 29, no. 12, pp. 1529-1533, 2012.

[100] M. S. Uddin and A. B. Upaganlawar, Oxidative Stress and Antioxidant Defense: Biomedical Value in Health and Diseases, Nova Science Publishers, Hauppauge, NY, USA, 2019.

[101] A. Vinik, J. Ullal, H. K. Parson, and C. M. Casellini, "Diabetic neuropathies: clinical manifestations and current treatment options," Nature Clinical Practice Endocrinology \& Metabolism, vol. 2, no. 5, pp. 269-281, 2006.

[102] J. F. Edwards, C. M. Casellini, H. K. Parson, I. G. Obrosova, M. Yorek, and A. I. Vinik, "Role of peroxynitrite in the development of diabetic peripheral neuropathy," Diabetes Care, vol. 38, no. 7, pp. e100-e101, 2015.

[103] N. E. Cameron, T. M. Gibson, M. R. Nangle, and M. A. Cotter, "Inhibitors of advanced glycation end product formation and neurovascular dysfunction in experimental diabetes," Annals of the New York Academy of Sciences, vol. 1043, no. 1, pp. 784-792, 2005.

[104] S. Y. Rhee and Y. S. Kim, "The role of advanced glycation end products in diabetic vascular complications," Diabetes \& Metabolism Journal, vol. 42, no. 3, pp. 188-195, 2018.

[105] P. S. Van Dam, M. A. Cotter, B. Bravenboer, and N. E. Cameron, "Pathogenesis of diabetic neuropathy: focus on neurovascular mechanisms," European Journal of Pharmacology, vol. 719, no. 1-3, pp. 180-186, 2013.

[106] I. G. Obrosova, R. Stavniichuk, V. R. Drel et al., "Different roles of 12/15-lipoxygenase in diabetic large and small fiber peripheral and autonomic neuropathies," The American Journal of Pathology, vol. 177, no. 3, pp. 1436-1447, 2010.

[107] J. Eichberg, "Protein kinase C changes in diabetes: is the concept relevant to neuropathy?" International Review of Neurobiology, vol. 50, pp. 61-82, 2002.

[108] P. Geraldes and G. L. King, "Activation of protein kinase C isoforms and its impact on diabetic complications," Circulation Research, vol. 106, no. 8, pp. 1319-1331, 2010.

[109] T. Sasase, H. Yamada, K. Sakoda et al., "Novel protein kinase C- $\beta$ isoform selective inhibitor JTT-010 ameliorates both hyper- and hypoalgesia in streptozotocin- induced diabetic rats," Diabetes, Obesity and Metabolism, vol. 7, no. 5, pp. 586-594, 2005.

[110] J. L. Edwards, A. Quattrini, S. I. Lentz et al., "Diabetes regulates mitochondrial biogenesis and fission in mouse neurons," Diabetologia, vol. 53, no. 1, pp. 160-169, 2010.

[111] A. M. Vincent, L. L. Mclean, C. Backus, and E. L. Feldman, "Short-term hyperglycemia produces oxidative damage and apoptosis in neurons," The FASEB Journal, vol. 19, no. 6, pp. 1-24, 2005.

[112] E. Zherebitskaya, E. Akude, D. R. Smith, and P. Fernyhough, "Development of selective axonopathy in adult sensory neurons isolated from diabetic rats: role of glucose-induced oxidative stress," Diabetes, vol. 58, no. 6, pp. 1356-1364, 2009.

[113] J. Doupis, T. E. Lyons, S. Wu, C. Gnardellis, T. Dinh, and A. Veves, "Microvascular reactivity and inflammatory cytokines in painful and painless peripheral diabetic neuropathy," The Journal of Clinical Endocrinology \& Metabolism, vol. 94, no. 6, pp. 2157-2163, 2009.

[114] G. Conti, E. Scarpini, P. Baron et al., "Macrophage infiltration and death in the nerve during the early phases of experimental diabetic neuropathy: a process concomitant with endoneurial induction of IL- $1 \beta$ and p75NTR," Journal of the Neurological Sciences, vol. 195, no. 1, pp. 35-40, 2002.

[115] S. I. Yamagishi, S. Ogasawara, H. Mizukami et al., "Correction of protein kinase $\mathrm{C}$ activity and macrophage migration in peripheral nerve by pioglitazone, peroxisome proliferator activated- $\gamma$ - ligand, in insulin-deficient diabetic rats," Journal of Neurochemistry, vol. 104, no. 2, pp. 491-499, 2008.

[116] B. Andorfer, B. C. Kieseier, E. Mathey et al., "Expression and distribution of transcription factor NF- $\kappa \mathrm{B}$ and inhibitor $\mathrm{I} \kappa \mathrm{B}$ in the inflamed peripheral nervous system," Journal of Neuroimmunology, vol. 116, no. 2, pp. 226-232, 2001.

[117] H. C. Ha, L. D. Hester, and S. H. Snyder, "Poly(ADP-ribose) polymerase-1 dependence of stress-induced transcription factors and associated gene expression in glia," Proceedings of the National Academy of Sciences, vol. 99, no. 5, pp. 32703275, 2002.

[118] A. Bierhaus, K.-M. Haslbeck, P. M. Humpert et al., "Loss of pain perception in diabetes is dependent on a receptor of the immunoglobulin superfamily," Journal of Clinical Investigation, vol. 114, no. 12, pp. 1741-1751, 2004.

[119] S. C. Apfel, "Neurotrophic factors in the therapy of diabetic neuropathy," The American Journal of Medicine, vol. 107, no. 2, pp. 34-42, 1999.

[120] J.-O. Jeong, M.-O. Kim, H. Kim et al., "Dual angiogenic and neurotrophic effects of bone marrow-derived endothelial progenitor cells on diabetic neuropathy," Circulation, vol. 119, no. 5, pp. 699-708, 2009.

[121] S. Tyagi, S. Sharma, P. Gupta, A. Saini, and C. Kaushal, "The peroxisome proliferator-activated receptor: a family of nuclear receptors role in various diseases," Journal of Advanced Pharmaceutical Technology \& Research, vol. 2, no. 4, pp. 236-240, 2011.

[122] L. Michalik and W. Wahli, "Involvement of PPAR nuclear receptors in tissue injury and wound repair," Journal of Clinical Investigation, vol. 116, no. 3, pp. 598-606, 2006.

[123] M. S. Uddin, M. T. Kabir, M. Jakaria et al., "Endothelial $\operatorname{PPAR} \gamma$ is crucial for averting age-related vascular dysfunction by stalling oxidative stress and ROCK," Neurotoxicity Research, vol. 36, no. 3, pp. 583-601, 2019.

[124] C. Janani and B. D. Ranjitha Kumari, "PPAR gamma gene-a review," Diabetes \& Metabolic Syndrome: Clinical Research \& Reviews, vol. 9, no. 1, pp. 46-50, 2015.

[125] A. C. P. Oliveira, C. M. Bertollo, L. T. S. Rocha, E. B. Nascimento, K. A. Costa, and M. M. Coelho, "Antinociceptive and antiedematogenic activities of fenofibrate, an agonist of PPAR alpha, and pioglitazone, an agonist of PPAR gamma," European Journal of Pharmacology, vol. 561, no. 1-3, pp. 194-201, 2007.

[126] C. M. Freitag and R. J. Miller, "Peroxisome proliferatoractivated receptor agonists modulate neuropathic pain: a link to chemokines?" Frontiers in Cellular Neuroscience, vol. 8, p. 238, 2014. 
[127] A. D. Mooradian, J. Chehade, and J. E. Thurman, "The role of thiazolidinediones in the treatment of patients with type 2 diabetes mellitus," Treatments in Endocrinology, vol. 1, no. 1, pp. 13-20, 2002.

[128] R. B. Griggs, R. R. Donahue, B. G. Adkins, K. L. Anderson, O. Thibault, and B. K. Taylor, "Pioglitazone inhibits the development of hyperalgesia and sensitization of spinal nociresponsive neurons in type 2 diabetes," The Journal of Pain, vol. 17, no. 3, pp. 359-373, 2016.

[129] B. N. Okine, J. C. Gaspar, and D. P. Finn, "PPARs and pain," British Journal of Pharmacology, vol. 176, no. 10, pp. 14211442, 2019.

[130] B. S. Galer, A. Gianas, and M. P. Jensen, "Painful diabetic polyneuropathy: epidemiology, pain description, and quality of life," Diabetes Research and Clinical Practice, vol. 47, no. 2, pp. 123-128, 2000.

[131] A. C. Themistocleous, J. D. Ramirez, P. R. Shillo et al., "The Pain in Neuropathy Study (PiNS): a cross-sectional observational study determining the somatosensory phenotype of painful and painless diabetic neuropathy," Pain, vol. 157, no. 5, pp. 1132-1145, 2016.

[132] J. Raputova, I. Srotova, E. Vlckova et al., "Sensory phenotype and risk factors for painful diabetic neuropathy: a crosssectional observational study," Pain, vol. 158, no. 12, pp. 2340-2353, 2017.

[133] P. A. Low, K. K. Nickander, and H. J. Tritschler, “The roles of oxidative stress and antioxidant treatment in experimental diabetic neuropathy," Diabetes, vol. 46, no. 2, pp. S38-S42, 1997.

[134] F. J. Romero, “Antioxidants in peripheral nerve," Free Radical Biology and Medicine, vol. 20, no. 7, pp. 925-932, 1996.

[135] D. K. Sahoo, A. Roy, and G. B. N. Chainy, "Protective effects of vitamin $\mathrm{E}$ and curcumin on l-thyroxine-induced rat testicular oxidative stress," Chemico-Biological Interactions, vol. 176, no. 2-3, pp. 121-128, 2008.

[136] L. Packer, E. H. Witt, and H. J. Tritschler, "Alpha-lipoic acid as a biological antioxidant," Free Radical Biology and Medicine, vol. 19, no. 2, pp. 227-250, 1995.

[137] D. Ziegler, M. Hanefeld, K. J. Ruhnau et al., “Treatment of symptomatic diabetic polyneuropathy with the antioxidant alpha-lipoic acid: a 7-month multicenter randomized controlled trial (ALADIN III Study). ALADIN III study group. Alpha-lipoic acid in diabetic neuropathy," Diabetes Care, vol. 22, no. 8, pp. 1296-1301, 1999.

[138] M. Nagamatsu, K. K. Nickander, J. D. Schmelzer et al., "Lipoic acid improves nerve blood flow, reduces oxidative stress, and improves distal nerve conduction in experimental diabetic neuropathy," Diabetes Care, vol. 18, no. 8, pp. 1160-1167, 1995.

[139] N. E. Cameron, M. A. Cotter, V. Archibald, K. C. Dines, and E. K. Maxfield, "Anti-oxidant and pro-oxidant effects on nerve conduction velocity, endoneurial blood flow and oxygen tension in non-diabetic and streptozotocin-diabetic rats," Diabetologia, vol. 37, no. 5, pp. 449-459, 1994.

[140] S. S. Al-Rejaie, A. M. Aleisa, H. M. Abuohashish et al., "Naringenin neutralises oxidative stress and nerve growth factor discrepancy in experimental diabetic neuropathy," Neurological Research, vol. 37, no. 10, pp. 924-933, 2015.

[141] A. D. Kandhare, K. S. Raygude, P. Ghosh, A. E. Ghule, and S. L. Bodhankar, "Neuroprotective effect of naringin by modulation of endogenous biomarkers in streptozotocin induced painful diabetic neuropathy," Fitoterapia, vol. 83, no. 4, pp. 650-659, 2012.
[142] O. Ates, S. R. Cayli, N. Yucel et al., "Central nervous system protection by resveratrol in streptozotocin-induced diabetic rats," Journal of Clinical Neuroscience, vol. 14, no. 3, pp. 256-260, 2007.

[143] W.-C. Zhao, B. Zhang, M.-J. Liao et al., "Curcumin ameliorated diabetic neuropathy partially by inhibition of $\mathrm{NADPH}$ oxidase mediating oxidative stress in the spinal cord," Neuroscience Letters, vol. 560, pp. 81-85, 2014.

[144] D. Jain, M. K. Bansal, R. Dalvi, A. Upganlawar, and R. Somani, "Protective effect of diosmin against diabetic neuropathy in experimental rats," Journal of Integrative Medicine, vol. 12, no. 1, pp. 35-41, 2014.

[145] G. Ristagno, F. Fumagalli, C. Porretta-Serapiglia et al., "Hydroxytyrosol attenuates peripheral neuropathy in streptozotocin-induced diabetes in rats," Journal of Agricultural and Food Chemistry, vol. 60, no. 23, pp. 5859-5865, 2012.

[146] O. R. Ayepola, M. E. Cerf, N. L. Brooks, and O. O. Oguntibeju, "Kolaviron, a biflavonoid complex of Garcinia kola seeds modulates apoptosis by suppressing oxidative stress and inflammation in diabetes-induced nephrotoxic rats," Phytomedicine, vol. 21, no. 14, pp. 1785-1793, 2014.

[147] W. Deng, H. Lu, and J. Teng, "Carvacrol attenuates diabetesassociated cognitive deficits in rats," Journal of Molecular Neuroscience, vol. 51, no. 3, pp. 813-819, 2013.

[148] E. S. H. Abd Allah and A. M. S. Gomaa, "Effects of curcumin and captopril on the functions of kidney and nerve in streptozotocin-induced diabetic rats: role of angiotensin converting enzyme 1," Applied Physiology, Nutrition, and Metabolism, vol. 40, no. 10, pp. 1061-1067, 2015.

[149] B. Nagilla and K. P. Reddy, "Neuroprotective and antinociceptive effect of curcumin in diabetic neuropathy in rats," International Journal of Pharmacy and Pharmaceutical Sciences, vol. 6, no. 5, pp. 131-138, 2014.

[150] H. N. Attia, N. M. Al-Rasheed, N. M. Al-Rasheed, Y. A. Maklad, A. A. E. Ahmed, and S. A. B. Kenawy, "Protective effects of combined therapy of gliclazide with curcumin in experimental diabetic neuropathy in rats," Behavioural Pharmacology, vol. 23, no. 2, pp. 153-161, 2012.

[151] S. Sharma, K. Chopra, and S. K. Kulkarni, "Effect of insulin and its combination with resveratrol or curcumin in attenuation of diabetic neuropathic pain: participation of nitric oxide and TNF-alpha," Phytotherapy Research, vol. 21, no. 3, pp. 278-283, 2007.

[152] J. Yu, Y. Zhang, S. Sun et al., "Inhibitory effects of astragaloside IV on diabetic peripheral neuropathy in rats," Canadian Journal of Physiology and Pharmacology, vol. 84, no. 6, pp. 579-587, 2006.

[153] D. Raposo, C. Morgado, P. Pereira-Terra, and I. Tavares, "Nociceptive spinal cord neurons of laminae I-III exhibit oxidative stress damage during diabetic neuropathy which is prevented by early antioxidant treatment with epigallocatechin-gallate (EGCG)," Brain Research Bulletin, vol. 110, pp. 68-75, 2015.

[154] T. Baluchnejadmojarad and M. Roghani, "Chronic oral epigallocatechin-gallate alleviates streptozotocin-induced diabetic neuropathic hyperalgesia in rat: involvement of oxidative stress," Iranian Journal of Pharmaceutical Research: IJPR, vol. 11, no. 4, pp. 1243-1253, 2012.

[155] Y. Ding, X. Dai, Y. Jiang, Z. Zhang, and Y. Li, "Functional and morphological effects of grape seed proanthocyanidins on peripheral neuropathy in rats with type 2 diabetes 
mellitus," Phytotherapy Research, vol. 28, no. 7, pp. 1082-1087, 2014.

[156] L. Kishore, N. Kaur, and R. Singh, "Bacosine isolated from aerial parts of Bacopa monnieri improves the neuronal dysfunction in streptozotocin-induced diabetic neuropathy," Journal of Functional Foods, vol. 34, pp. 237-247, 2017.

[157] S. Akbar, F. Subhan, N. Karim et al., "6-Methoxyflavanone attenuates mechanical allodynia and vulvodynia in the streptozotocin-induced diabetic neuropathic pain," Biomedicine \& Pharmacotherapy, vol. 84, pp. 962-971, 2016.

[158] D. Bagdas, H. Y. Ozboluk, N. Cinkilic, and M. S. Gurun, "Antinociceptive effect of chlorogenic acid in rats with painful diabetic neuropathy," Journal of Medicinal Food, vol. 17, no. 6, pp. 730-732, 2014.

[159] H. I. Rocha-González, M. Ramírez-Aguilar, V. GranadosSoto et al., "Antineuropathic effect of 7-hydroxy-3,4-dihydrocadalin in streptozotocin-induced diabetic rodents," BMC Complementary and Alternative Medicine, vol. 14, no. 1, 2014.

[160] S. T. Ma, D. L. Liu, J. J. Deng, and Y. J. Peng, "Protective effect of mulberry flavonoids on sciatic nerve in alloxaninduced diabetic rats," Brazilian Journal of Pharmaceutical Sciences, vol. 50, no. 4, pp. 765-772, 2014.

[161] N. Kaur, L. Kishore, and R. Singh, "Chromane isolated from leaves of dillenia indica improves the neuronal dysfunction in STZ-induced diabetic neuropathy," Journal of Ethnopharmacology, vol. 206, pp. 19-30, 2017.

[162] O. M. Abo-Salem, "Kaempferol attenuates the development of diabetic neuropathic pain in mice: possible anti-inflammatory and anti-oxidant mechanisms," Open Access Macedonian Journal of Medical Sciences, vol. 2, no. 3, pp. 424-430, 2014.

[163] S. B. Ghatak and S. S. Panchal, "Protective effect of oryzanol isolated from crude rice bran oil in experimental model of diabetic neuropathy," Revista Brasileira de Farmacognosia, vol. 22, no. 5, pp. 1092-1103, 2012.

[164] C.-T. Ma, C.-C. Chyau, C.-C. Hsu et al., "Pepino polyphenolic extract improved oxidative, inflammatory and glycative stress in the sciatic nerves of diabetic mice," Food \& Function, vol. 7, no. 2, pp. 1111-1121, 2016.

[165] K. Dureshahwar, M. Mubashir, and H. Une, "Quantification of quercetin obtained from Allium cepa Lam. leaves and its effects on streptozotocin-induced diabetic neuropathy," Pharmacognosy Research, vol. 9, no. 3, pp. 287-293, 2017.

[166] A. D. Kandhare, K. S. Raygude, V. Shiva Kumar et al., "Ameliorative effects quercetin against impaired motor nerve function, inflammatory mediators and apoptosis in neonatal streptozotocin-induced diabetic neuropathy in rats," Biomedicine \& Aging Pathology, vol. 2, no. 4, pp. 173-186, 2012.

[167] M. Anjaneyulu and K. Chopra, "Quercetin, a bioflavonoid, attenuates thermal hyperalgesia in a mouse model of diabetic neuropathic pain," Progress in Neuro-Psychopharmacology and Biological Psychiatry, vol. 27, no. 6, pp. 1001-1005, 2003.

[168] M. Anjaneyulu and K. Chopra, "Quercetin attenuates thermal hyperalgesia and cold allodynia in STZ-induced diabetic rats," Indian Journal of Experimental Biology, vol. 42, no. 8, pp. 766-769, 2004.

[169] A. Kumar, R. K. Kaundal, S. Iyer, and S. S. Sharma, "Effects of resveratrol on nerve functions, oxidative stress and DNA fragmentation in experimental diabetic neuropathy," Life Sciences, vol. 80, no. 13, pp. 1236-1244, 2007.

[170] A. Kumar and S. S. Sharma, "NF- $\kappa$ B inhibitory action of resveratrol: a probable mechanism of neuroprotection in experimental diabetic neuropathy," Biochemical and Biophysical Research Communications, vol. 394, no. 2, pp. 360-365, 2010.

[171] H. E. Mohamed, S. E. El-Swefy, R. A. Hasan, and A. A. Hasan, "Neuroprotective effect of resveratrol in diabetic cerebral ischemic-reperfused rats through regulation of inflammatory and apoptotic events," Diabetology \& Metabolic Syndrome, vol. 6, no. 1, p. 88, 2014.

[172] S. Sharma, M. Anjaneyulu, S. K. Kulkarni, and K. Chopra, "Resveratrol, a polyphenolic phytoalexin, attenuates diabetic nephropathy in rats," Pharmacology, vol. 76, no. 2, pp. 69-75, 2006.

[173] T. Baluchnejadmojarad, M. Roghani, and M. Mafakheri, "Neuroprotective effect of silymarin in 6-hydroxydopamine hemi-parkinsonian rat: involvement of estrogen receptors and oxidative stress," Neuroscience Letters, vol. 480, no. 3, pp. 206-210, 2010.

[174] S. Alsharari, S. Al-Rejaie, H. Abuohashish, A. Aleisa, M. Parmar, and M. Ahmed, "Ameliorative potential of morin in streptozotocin-induced neuropathic pain in rats," Tropical Journal of Pharmaceutical Research, vol. 13, no. 9, pp. 1429-1436, 2014.

[175] C. Sommer and M. Kress, "Recent findings on how proinflammatory cytokines cause pain: peripheral mechanisms in inflammatory and neuropathic hyperalgesia," Neuroscience Letters, vol. 361, no. 1-3, pp. 184-187, 2004.

[176] M. Schäfers, C. I. Svensson, C. Sommer, and L. S. Sorkin, "Tumor necrosis factor- $\alpha$ induces mechanical allodynia after spinal nerve ligation by activation of p38 MAPK in primary sensory neurons," The Journal of Neuroscience, vol. 23, no. 7, pp. 2517-2521, 2003.

[177] J. M. González-Clemente, D. Mauricio, C. Richart et al., "Diabetic neuropathy is associated with activation of the TNF- $\alpha$ system in subjects with type 1 diabetes mellitus," Clinical Endocrinology, vol. 63, no. 5, pp. 525-529, 2005.

[178] D. M. Shafer, L. Assael, L. B. White, and E. F. Rossomando, "Tumor necrosis factor- $\alpha$ as a biochemical marker of pain and outcome in temporomandibular joints with internal derangements," Journal of Oral and Maxillofacial Surgery, vol. 52, no. 8, pp. 786-791, 1994.

[179] J. Satoh, S. Yagihashi, and T. Toyota, "The possible role of tumor necrosis factor- $\alpha$ in diabetic polyneuropathy," Experimental Diabesity Research, vol. 4, no. 2, pp. 65-71, 2003.

[180] N. Cameron and M. Cotter, "Pro-inflammatory mechanisms in diabetic neuropathy: focus on the nuclear factor kappa B pathway," Current Drug Targets, vol. 9, no. 1, pp. 60-67, 2008.

[181] J. Copray, I. Mantingh, N. Brouwer et al., "Expression of interleukin-1 beta in rat dorsal root ganglia," Journal of Neuroimmunology, vol. 118, no. 2, pp. 203-211, 2001.

[182] J. M. Cunha, F. Q. Cunha, S. Poole, and S. H. Ferreira, "Cytokine-mediated inflammatory hyperalgesia limited by interleukin-1 receptor antagonist," British Journal of Pharmacology, vol. 130, no. 6, pp. 1418-1424, 2000.

[183] M. Bujalska, J. Tatarkiewicz, A. de Cordé, and S. W. Gumułka, "Effect of cyclooxygenase and nitric oxide synthase inhibitors on streptozotocin-induced hyperalgesia in rats," Pharmacology, vol. 81, no. 2, pp. 151-157, 2008

[184] A. P. Kellogg, T. D. Wiggin, D. D. Larkin, J. M. Hayes, M. J. Stevens, and R. Pop-Busui, "Protective effects of cyclooxygenase- 2 gene inactivation against peripheral nerve dysfunction and intraepidermal nerve fiber loss in experimental diabetes," Diabetes, vol. 56, no. 12, pp. 2997-3005, 2007. 
[185] S. Park, K. Sapkota, S. Kim, H. Kim, and S. Kim, "Kaempferol acts through mitogen-activated protein kinases and protein kinase B/AKT to elicit protection in a model of neuroinflammation in BV2 microglial cells," British Journal of Pharmacology, vol. 164, no. 3, pp. 1008-1025, 2011.

[186] T. Baluchnejadmojarad, M. Roghani, and Z. Khastehkhodaie, "Chronic treatment of silymarin improves hyperalgesia and motor nerve conduction velocity in diabetic neuropathic rat," Phytotherapy Research, vol. 24, no. 8, pp. 1120-1125, 2010.

[187] K. R. Shieh, C. H. Yi, T. T. Liu et al., "Evidence for neurotrophic factors associating with TRPV1 gene expression in the inflamed human esophagus," Neurogastroenterology \& Motility, vol. 22, no. 9, pp. 971-e252, 2010.

[188] V. A. Carozzi and C. Ceresa, "The role of glutamate in diabetic and in chemotherapy induced peripheral neuropathies and its regulation by glutamate carboxypeptidase II," Current Medicinal Chemistry, vol. 19, no. 9, pp. 1261-1268, 2012.

[189] L. Daulhac, C. Mallet, C. Courteix et al., "Diabetes-induced mechanical hyperalgesia involves spinal mitogen-activated protein kinase activation in neurons and microglia via N-Methyl-D-aspartate-dependent mechanisms," Molecular Pharmacology, vol. 70, no. 4, pp. 1246-1254, 2006.

[190] S. Fakhri, L. Dargahi, F. Abbaszadeh, and M. Jorjani, "Effects of astaxanthin on sensory-motor function in a compression model of spinal cord injury: involvement of ERK and AKT signalling pathway," European Journal of Pain, vol. 23, no. 4, pp. 750-764, 2019.

[191] S. Takehana, Y. Kubota, N. Uotsu et al., "The dietary constituent resveratrol suppresses nociceptive neurotransmission via the NMDA receptor," Molecular Pain, vol. 13, Article ID 174480691769701, 2017.

[192] R. Moldzio, K. Radad, C. Krewenka, B. Kranner, J. C. Duvigneau, and W.-D. Rausch, "Protective effects of resveratrol on glutamate-induced damages in murine brain cultures," Journal of Neural Transmission, vol. 120, no. 9, pp. 1271-1280, 2013.

[193] K. Zeng, N. Yang, D. Wang et al., "Resveratrol prevents retinal dysfunction by regulating glutamate transporters, glutamine synthetase expression and activity in diabetic retina," Neurochemical Research, vol. 41, no. 5, pp. 1050-1064, 2016.

[194] C. Girbovan and H. Plamondon, "Resveratrol downregulates type-1 glutamate transporter expression and microglia activation in the hippocampus following cerebral ischemia reperfusion in rats," Brain Research, vol. 1608, pp. 203-214, 2015.

[195] A. Quincozes-Santos, L. D. Bobermin, A. C. Tramontina et al., "Oxidative stress mediated by NMDA, AMPA/KA channels in acute hippocampal slices: neuroprotective effect of resveratrol," Toxicology in Vitro, vol. 28, no. 4, pp. 544-551, 2014.

[196] K. S. Cho, E. J. Lee, K. J. Kwon et al., "Resveratrol downregulates a glutamate-induced tissue plasminogen activator via Erk and AMPK/mTOR pathways in rat primary cortical neurons," Food \& Function, vol. 5, no. 5, pp. 951-960, 2014.

[197] Y. Chang and S.-J. Wang, "Inhibitory effect of glutamate release from rat cerebrocortical nerve terminals by resveratrol," Neurochemistry International, vol. 54, no. 2, pp. 135-141, 2009.

[198] Y. Son, S. J. Byun, and H.-O. Pae, "Involvement of heme oxygenase-1 expression in neuroprotection by piceatannol, a natural analog and a metabolite of resveratrol, against glutamate-mediated oxidative injury in HT22 neuronal cells," Amino Acids, vol. 45, no. 2, pp. 393-401, 2013.

[199] Y. Mikami and T. Yamazawa, "Chlorogenic acid, a polyphenol in coffee, protects neurons against glutamate neurotoxicity," Life Sciences, vol. 139, pp. 69-74, 2015.

[200] O. Rebai, M. Belkhir, M. V. Sanchez-Gomez, C. Matute, S. Fattouch, and M. Amri, "Differential molecular targets for neuroprotective effect of chlorogenic acid and its related compounds against glutamate induced excitotoxicity and oxidative stress in rat cortical neurons," Neurochemical Research, vol. 42, no. 12, pp. 3559-3572, 2017.

[201] J. Yu, Y. Jia, Y. Guo et al., "Epigallocatechin-3-gallate protects motor neurons and regulates glutamate level," FEBS Letters, vol. 584, no. 13, pp. 2921-2925, 2010.

[202] S. Pournourmohammadi, M. Grimaldi, M. H. Stridh et al., "Epigallocatechin-3-gallate (EGCG) activates AMPK through the inhibition of glutamate dehydrogenase in muscle and pancreatic $\beta$-cells: a potential beneficial effect in the pre-diabetic state?" The International Journal of Biochemistry \& Cell Biology, vol. 88, pp. 220-225, 2017.

[203] C.-W. Chou, W.-J. Huang, L.-T. Tien, and S.-J. Wang, "(-)-Epigallocatechin gallate, the most active polyphenolic catechin in green tea, presynaptically facilitates $\mathrm{Ca}^{2+}$-dependent glutamate release via activation of protein kinase $\mathrm{C}$ in rat cerebral cortex," Synapse, vol. 61, no. 11, pp. 889-902, 2007.

[204] J.-H. Lee, D.-K. Song, C.-H. Jung et al., “(-)-Epigallocatechin gallate attenuates glutamate-induced cytotoxicity via intracellular $\mathrm{Ca}^{2+}$ modulation in PC12 cells," Clinical and Experimental Pharmacology and Physiology, vol. 31, no. 8, pp. 530-536, 2004.

[205] C.-W. Lu, T.-Y. Lin, and S.-J. Wang, "Quercetin inhibits depolarization-evoked glutamate release in nerve terminals from rat cerebral cortex," Neurotoxicology, vol. 39, pp. 1-9, 2013.

[206] H.-C. Huang, P. Chang, S.-Y. Lu, B.-W. Zheng, and Z.-F. Jiang, "Protection of curcumin against amyloid- $\beta$-induced cell damage and death involves the prevention from NMDA receptor-mediated intracellular $\mathrm{Ca}^{2+}$ elevation," Journal of Receptors and Signal Transduction, vol. 35, no. 5, pp. 450-457, 2015.

[207] R. M. Khalil and N. F. Khedr, "Curcumin protects against monosodium glutamate neurotoxicity and decreasing NMDA2B and mGluR5 expression in rat hippocampus," NeuroSignals, vol. 24, no. 1, pp. 81-87, 2016.

[208] L. Zhang, T. Xu, S. Wang et al., "NMDA GluN2B receptors involved in the antidepressant effects of curcumin in the forced swim test," Progress in Neuro-Psychopharmacology and Biological Psychiatry, vol. 40, pp. 12-17, 2013.

[209] S. Jayanarayanan, S. Smijin, K. T. Peeyush, T. R. Anju, and C. S. Paulose, "NMDA and AMPA receptor mediated excitotoxicity in cerebral cortex of streptozotocin induced diabetic rat: ameliorating effects of curcumin," ChemicoBiological Interactions, vol. 201, no. 1-3, pp. 39-48, 2013.

[210] T. Y. Lin, C. W. Lu, S. K. Huang, and S. J. Wang, "Curcumin inhibits glutamate release from rat prefrontal nerve endings by affecting vesicle mobilization," International Journal of Molecular Sciences, vol. 13, no. 7, pp. 9097-9109, 2012.

[211] P. Srivastava, Y. K. Dhuriya, V. Kumar et al., "PI3K/Akt/ GSK $3 \beta$ induced CREB activation ameliorates arsenic mediated alterations in NMDA receptors and associated signaling in rat hippocampus: neuroprotective role of curcumin," Neurotoxicology, vol. 67, pp. 190-205, 2018. 
[212] G. S. B. Aseervatham, U. Suryakala, Doulethunisha, S. Sundaram, P. C. Bose, and T. Sivasudha, "Expression pattern of NMDA receptors reveals antiepileptic potential of apigenin 8-C-glucoside and chlorogenic acid in pilocarpine induced epileptic mice," Biomedicine \& Pharmacotherapy, vol. 82, pp. 54-64, 2016.

[213] A. Ramakrishnan, N. Vijayakumar, and M. Renuka, "Naringin regulates glutamate-nitric oxide cGMP pathway in ammonium chloride induced neurotoxicity," Biomedicine \& Pharmacotherapy, vol. 84, pp. 1717-1726, 2016.

[214] R. Yue, X. Li, B. Chen et al., "Astragaloside IV attenuates glutamate-induced neurotoxicity in PC12 cells through RafMEK-ERK pathway," PLoS One, vol. 10, no. 5, Article ID e0126603, 2015.

[215] E.-J. Yang, G.-S. Kim, M. Jun, and K.-S. Song, "Kaempferol attenuates the glutamate-induced oxidative stress in mousederived hippocampal neuronal HT22 cells," Food \& Function, vol. 5, no. 7, pp. 1395-1402, 2014.

[216] E. Eisenberg, E. D. McNicol, and D. B. Carr, "Opioids for neuropathic pain," Cochrane Database of Systematic Reviews, vol. 19, no. 2, Article ID CD006146, 2006.

[217] H. Cory, S. Passarelli, J. Szeto, M. Tamez, and J. Mattei, "The role of polyphenols in human health and food systems: a mini-review," Frontiers in Nutrition, vol. 5, p. 87, 2018.

[218] S. Lecour and K. T. Lamont, "Natural polyphenols and cardioprotection," Mini-Reviews in Medicinal Chemistry, vol. 11, no. 14, pp. 1191-1199, 2011. 